\title{
High manganese and nickel concentrations in human hair and well water and low calcium concentration in blood serum in a pristine area with sulphide-rich bedrock
}

\author{
Anne Kousa (i) Kirsti Loukola-Ruskeeniemi - Tarja Hatakka • \\ Marjatta Kantola
}

Received: 25 May 2021 / Accepted: 9 October 2021 / Published online: 26 October 2021

(C) The Author(s) 2021

\begin{abstract}
We report the trace element status of residents living in areas with naturally sulphide-rich bedrock and soil in two municipalities in Finland, Sotkamo and Kaavi. Altogether, 225 people from these sparsely populated regions participated voluntarily by providing hair and blood samples. The concentrations of calcium, zinc and copper in serum as well as selenium and cadmium in whole blood did not show correlation with those concentrations in hair samples. Calcium concentration in serum was slightly lower in the sulphide-rich areas (median value $91.4 \mathrm{mg} / \mathrm{l}, n=103$ ) than in the areas with adjacent sulphur-poor bedrock (median value $93.6 \mathrm{mg} / \mathrm{l}$, $n=82$ ). The concentrations of $\mathrm{Ni}$ and $\mathrm{Mn}$ in hair correlated with those in drinking water. The highest $\mathrm{Mn}$ and Ni concentrations in the water samples from private wells were $1620 \mu \mathrm{g} / \mathrm{l}$ and $51 \mu \mathrm{g} / \mathrm{l}$ and the highest concentrations in human hair samples $36.44 \mathrm{mg} / \mathrm{kg}$ and $12.3 \mathrm{mg} / \mathrm{kg}$, respectively. The challenge with elevated trace element concentrations in
\end{abstract}

A. Kousa

Environmental Solutions, Geological Survey of Finland GTK, P.O. Box 1237, 70211 Kuopio, Finland

K. Loukola-Ruskeeniemi ( $\square) \cdot$ T. Hatakka Environmental Solutions, Geological Survey of Finland GTK, P.O. Box 96, 02151 Espoo, Finland e-mail: kirsti.loukola-ruskeeniemi@gtk.fi

M. Kantola

Natural Resources Institute Finland (Luke), P.O. Box 2, 00791 Helsinki, Finland some well waters is well documented. In northern countries (Finland, Sweden, Norway and Canada), only $10 \%$ of the population depend on private well water, and $90 \%$ have access to monitored municipal water supplies. Compared with data available from sulphide mine sites globally, the nickel and manganese concentrations in human hair samples were high in our sulphide-rich study area at Sotkamo representing the trace element status of residents under natural conditions.

Keywords Manganese $\cdot$ Nickel $\cdot$ Hair · Ground water $\cdot$ Well water $\cdot$ Medical geology $\cdot$ Geogenic

\section{Introduction}

Sulphide-rich bedrock is reflected in elevated concentrations of potentially harmful elements in soil, surface water and groundwater, as well as in organic stream and lake sediments (e.g. Gustavsson et al., 2011, 2012; Loukola-Ruskeeniemi et al., 1998, 2003). Our study focuses on sulphidic black shales which are sedimentary rocks containing $>0.5 \%$ organic, non-carbonate carbon. They host sulphide deposits and occurrences that have been mined for $\mathrm{Cu}, \mathrm{Ni}, \mathrm{Zn}, \mathrm{Mn}, \mathrm{P}, \mathrm{Mo}, \mathrm{V}, \mathrm{U}$, $\mathrm{Au}$ and platinum group elements. During weathering, acid neutralization potential varies depending on adjacent rock units, and especially on the presence of Ca-rich rocks. Hazardous environmental impacts 
may occur if the bedrock is in contact with surface water (Kim \& Thornton, 1993; Loukola-Ruskeeniemi, 1992; Parviainen \& Loukola-Ruskeeniemi, 2019; Piispanen \& Nykyri, 1997). In addition to black shales, other sulphide-rich rocks may serve as natural sources of contamination for surface waters and groundwater. The bedrock in eastern and northern parts of Finland contains sulphide-rich black shales with the thickness from tens of meters to several hundreds of meters due to the folding of the black shale units during tectonic deformation (LoukolaRuskeeniemi, 1999). Exposure to trace elements originating from anthropogenic sources or occupational exposure has been well documented (e.g. Chen et al., 2018; Gil et al., 2011), but the potential health effects on the population following long-term lowdose exposure to elements originating from the natural geological environment have not been well characterized (Amaral et al., 2008). Previous studies have demonstrated that long-term exposure to harmful substances, even at low levels, can cause health risks (Loukola-Ruskeeniemi et al., 1999, 2003; O'Neal and Zheng 2015). Begum et al. (2015) analysed Fe, Mn, $\mathrm{Ni}, \mathrm{Cr}$ and $\mathrm{Co}$ concentrations in drinking water in densely populated areas of Pakistan having mafic and ultramafic bedrock. These rock types mainly contain mafic minerals such as olivine, pyroxene, serpentine and amphibole, which are rich in magnesium, calcium, iron, chromium and nickel. The inhabitants obtain their household water from groundwater and surface water sources. The authors report that the main sources of trace metals were geogenic, and mafic and ultramafic rocks were the main sources, especially for Ni and $\mathrm{Cr}$ (Begum et al., 2015).

Conventional and behavioural factors, as well as psychosocial ones, are risk factors for chronic diseases (Khot et al., 2003; Pänkäläinen et al., 2015; SinghManoux et al., 2018). However, elevated trace element concentrations in drinking water and food are also implicated, and an association has been proposed between environmental factors in well water and the incidence of chronic diseases (Kousa et al., 2006, 2012; Rubenowitz et al., 2000). An association between low $\mathrm{Mg}$ concentrations in groundwater and the increased risk of coronary heart disease has been reported in both Finland and Sweden (Kousa et al., 2008; Rubenowitz et al., 2000), as well as elsewhere (Jiang et al., 2016; McLeod et al., 2018). A low dietary $\mathrm{Mg}$ intake is associated with an increased risk of type 2 diabetes (Barbagallo \& Dominguez, 2007). Arsenic, fluoride and nitrate concentrations in drinking water are suggested as potential environmental risk factors for type 1 diabetes (Chafe et al., 2018; Moltchanova et al., 2004). According to a Danish study, Mn in drinking water is associated with attention-deficit hyperactivity disorder (ADHD) (Schullehner et al., 2020).

Trace element concentrations in hair vary among the general population (Rodushkin et al. 2000). These concentrations may be associated with age, sex, hair dyes, lifestyle factors such as smoking, dietary habits and the geochemical environment. The trace element composition of scalp hair reflects long-term exposure and is not transiently disturbed by each meal, while blood and urine reflect the current or acute status of trace elements (Munakata et al., 2006; Razagui \& Ghribi, 2005; Viana et al., 2014). Hair may be a more stable indicator of exposure to trace elements, while the levels in blood and urine are comparably low and strictly regulated by homeostatic mechanisms (Razagui \& Ghribi, 2005). Ntihabose et al. (2018) reported that hair is a promising biomarker among children of environmental Mn exposure from drinking water, even at low levels (Ntihabose et al., 2018). Conversely, Skröder et al. (2017) reported that $\mathrm{Mn}$ in children's hair does not reflect the internal dose and should therefore not be used as a biomarker of this dose (Skröder et al., 2017). The elaboration of standard procedures, validation of hair mineral analysis and delivery of detailed methodologies with welldefined reference levels are all required (Bellesteros et al., 2017; Mikulewicz et al., 2013).

$\mathrm{Ni}$ and Mn naturally occur in water, soil and air and can be leached from soil and bedrock (e.g. Lahermo et al., 2002). In water, $\mathrm{Ni}$ is present in its soluble form as the free ion $\mathrm{Ni}^{2+}$ (Haber et al., 2017). In aquatic environments, the main oxidation states of $\mathrm{Mn}$ are $\mathrm{Mn}(\mathrm{II})$, which is the soluble and bioavailable form, and $\mathrm{Mn}(\mathrm{IV})$, which is the insoluble form. $\mathrm{Mn}$ (II) predominates in the $\mathrm{pH}$ range 4-7. The extent to which Mn dissolves in groundwater depends on the amount of oxygen, the length of residence and, to a lesser extent, the pH of the water (ATSDR 2012; Barbeau et al., 2011; Kousa et al., 2021).

Apart from drinking water, the general population may be exposed to Ni through ambient air, food and cigarette smoke. Exposure may also occur through dermal contact with nickel-plated jewellery (ATSDR 
2005a). Exposure to Ni from drinking water is usually lower than that from food (Haber et al., 2017). The absorption of $\mathrm{Ni}$ is low, $0.7-2.5 \%$, when it is ingested via food or under a non-fasted state. However, the absorption is higher, 25-27\%, when $\mathrm{Ni}$ is ingested via drinking water without food or under a fasted state (EFSA 2020). According to a report by EFSA (2020), oral exposure to Ni may be associated with eczematous flare-up reactions in the skin in nickel-sensitized persons after oral ingestion. The report also suggests that there may be an association between nickel exposure and adverse reproductive and developmental outcomes. No clear signs of neurotoxicity or cancer in humans with oral exposure have been reported (EFSA 2020). The results of an epidemiological crosssectional study from Greece indicate that men with high Ni concentrations in hair also have high cholesterol, LDL, albumin and Ca levels, and women with high $\mathrm{Ni}$ in hair are more prone to high glucose and triglyceride and low sodium levels (Sazakli \& Leotsinidis, 2017). Exposure to Mn may occur through food, drinking water, inhalation of air, dermal contact and the consumption of products containing an excess of Mn (ATSDR 2012). Bouchard et al. (2011) reported that the Mn levels in hair are significantly associated with the Mn intake from water, but not with the dietary intake. Exposure to Mn via drinking water can be associated with adverse neurological effects in children (ATSDR 2012; Bouchard et al., 2011). Mn in water has only been considered as a technical/aesthetic or cosmetic problem at the regulatory level. However, several more recent studies have reported that $\mathrm{Mn}$ derived from drinking water can be a health risk, especially for children (Bouchard et al., 2011; Oulhote et al., 2014).

Many elements, like zinc $(\mathrm{Zn})$, copper $(\mathrm{Cu})$ and selenium (Se), are essential micronutrients for humans. Via exposure to high oral doses, they can be toxic and cause health problems (ATSDR 2003; ATSDR 2005b; Bost et al., 2016). Exposure to high oral doses can associate gastrointestinal irritation (ATSDR 2003). An increased Cu/Zn-ratio and especially the $\mathrm{Cu}$ concentration in serum are associated with increased risk of incident infections in middleaged and elderly men in Eastern Finland (Laine et al., 2020). Cadmium (Cd) exposure is associated with increased serum $\mathrm{Cu} / \mathrm{Zn}$ ratios, especially in smokers (Satarug et al., 2018). Cd is a toxic element. Kidney and bone are the most sensitive targets following oral exposure and lung following inhalation exposure for Cd (ATSDR, 2008).

The role of dietary calcium in cardiovascular disease (CVD) is contradictory. The Australian study found no association between $\mathrm{Ca}$ intakes and risk of CVD mortality or myocardial infarction (Khan et al., 2015). Elevated serum total calcium levels were positively associated with hypertension among US adults (Sabanayagam \& Shankar, 2011). Rohrman et al. (2016) observed the modest positive associations between high-normal serum calcium concentrations and risk of cardiovascular diseases, but the underlying mineral metabolism and the exact mechanisms are currently unclear.

The Geological Survey of Finland (GTK) and the University of Eastern Finland (the University of Kuopio), in co-operation with the healthcare centres of two municipalities, Kaavi and Sotkamo, in eastern Finland, initiated a study on the migration of harmful elements from sulphidic black shales to aquatic ecosystems and on the risks to human health in 1997 (Loukola-Ruskeeniemi et al., 1999). Results from comprehensive studies on trace element concentrations in the bedrock, soil, surface waters, organic stream and lake sediments, crayfish (Astacus astacus) and northern pike (Esox lucius L.) in our study areas in Kaavi and Sotkamo have been published earlier together with the data on mercury concentrations of altogether 225 human hair samples (Loukola-Ruskeeniemi et al., 2003). The present study was mainly focused on the exposure to nickel (Ni) and manganese $(\mathrm{Mn})$ via the water from 82 private wells.

The natural geochemical background varies significantly across different rock types in our study areas (Gustavsson et al., 2011, 2012). A thorough understanding of the natural geochemical variation is important to protect the general population from long-term exposure. The aim of our study was to establish whether sulphide-rich bedrock is reflected under natural conditions in pristine areas in the trace element status, mainly $\mathrm{Ni}$ and $\mathrm{Mn}$, among residents. No studies have been conducted about trace element concentrations in human hair, blood serum and whole blood samples in different geochemical areas in Finland. Finally, we compared our results with those in the vicinity of mine environments in other countries. 


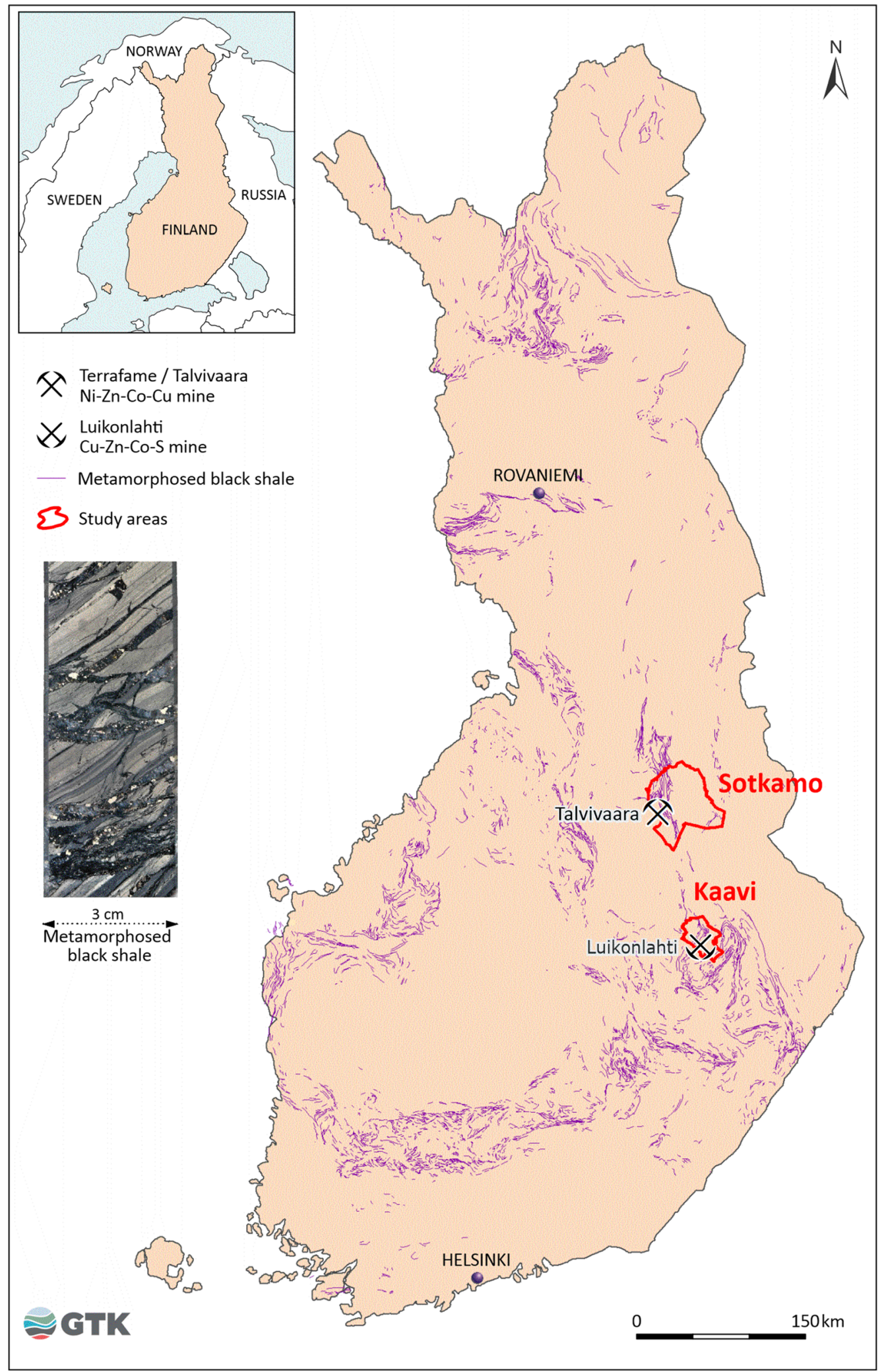


4Fig. 1 Location of the study areas and the Talvivaara Ni-Zn$\mathrm{Co}-\mathrm{Cu}$ mine (operating from year 2008) and the Luikonlahti $\mathrm{Cu}-\mathrm{Zn}-\mathrm{Co}-\mathrm{S}$ mine (operated during 1968-1983). The distribution of Precambrian schists rich in graphite and sulphides, socalled black shales, is from the black shale database of the Geological Survey of Finland (Arkimaa et al., 1999, 2000, Loukola-Ruskeeniemi et al., 2011, and Hyvönen et al., 2013)

\section{Methods}

Study areas

The data reported here were obtained from well water and human hair samples collected in 1999 from two sparsely inhabited municipalities, Kaavi and Sotkamo, in eastern Finland (Fig. 1). The study areas include units of black shales, i.e. sulphide- and graphite-rich metasedimentary rocks. The sample set was divided into black shale areas and reference areas representing other rock types with low concentrations of sulphur and graphitic carbon. The large Talvivaara $\mathrm{Ni}-\mathrm{Zn}-$ $\mathrm{Co}-\mathrm{Cu}$ mine currently operates in the Sotkamo black shale area (Loukola-Ruskeeniemi \& Heino, 1996). Mining activities began in 2008. As our sampling campaign was carried out in 1999, the results of the present study represent background levels. A sulphide mine has operated in the Kaavi study area as well but before our sampling campaign. The Luikonlahti mine with copper, zinc, cobalt and sulphur as the main products operated between 1968 and 1983 (Fig. 1).

\section{Water samples}

Altogether 82 water samples, mainly private well water in active household use, were taken late in the Finnish winter between 15 and 19 March 1999. Of these, 29 samples were collected from wells drilled into Precambrian crystalline bedrock and 50 samples from springs, captured springs and dug wells representing shallow groundwater in Quaternary deposits (Fig. 2 and Fig. 3). In the Sotkamo area, 24 water samples were taken from bedrock wells and 27 from Quaternary deposit wells. In the Kaavi area, five water samples were collected from bedrock wells and 23 from Quaternary deposit wells. All samples were taken via the kitchen taps to provide water samples representing the water the residents consume daily. Here we report mainly the soluble forms of $\mathrm{Mn}$ and $\mathrm{Ni}$

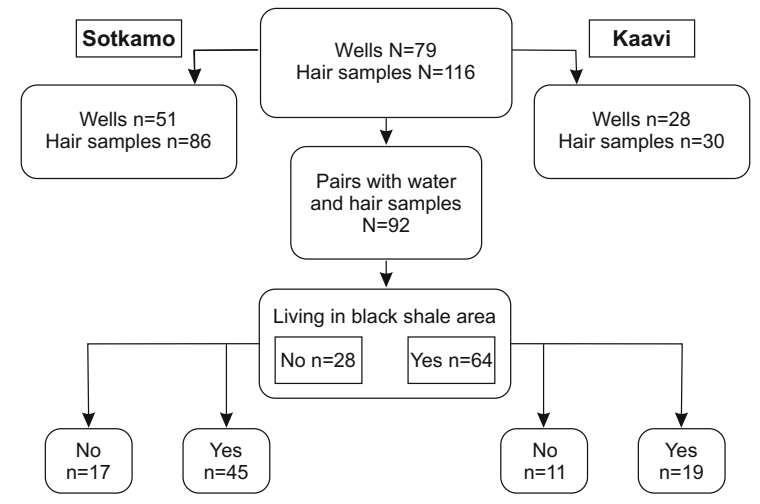

Fig. 2 The number of hair samples from voluntary participants using private well water was 92

in the water samples (filtered to $0.45 \mu \mathrm{m}$ and acidified with $0.5 \mathrm{ml} \mathrm{HNO}_{3} / 100 \mathrm{ml}$ water). However, the water samples were analysed in the accredited laboratory of the Geological Survey of Finland for major and trace elements using ICP-MS and ICP-AES methods and providing a long list of elements measured. Residents using municipal water were excluded, and only water samples from private wells were included in the study. The quantification limits in water were $0.02 \mu \mathrm{g} / \mathrm{l}$ for $\mathrm{Mn}$ and $0.06 \mu \mathrm{g} / \mathrm{l}$ for Ni. The chemical characteristics of well waters were combined with the attributes of participants from the same households. In statistical calculations, if the analysed $\mathrm{Mn}$ and $\mathrm{Ni}$ concentrations were below the limits of quantification, we used onehalf of the limit of quantification as the value. The quality of sampling was assured by including 5\% blank samples in each sample batch. Experienced and/ or certified personnel took the water samples. Water samples were analysed in an accredited laboratory using standard or accredited methods. The accredited laboratory enforced its customary quality assurance methods. Mn and $\mathrm{Ni}$ concentrations in the water samples from wells drilled into crystalline bedrock and shallow groundwater (springs, captured springs and dug wells) were processed and analysed separately for the black shale and reference areas.

\section{Hair samples}

Altogether 225 volunteers, 120 women and 105 men aged from 15 to 84 years, participated in the study. The medical staff of the municipal health centres of Sotkamo and Kaavi collected hair samples (Fig. 3). These samples were collected by cutting hair from the 


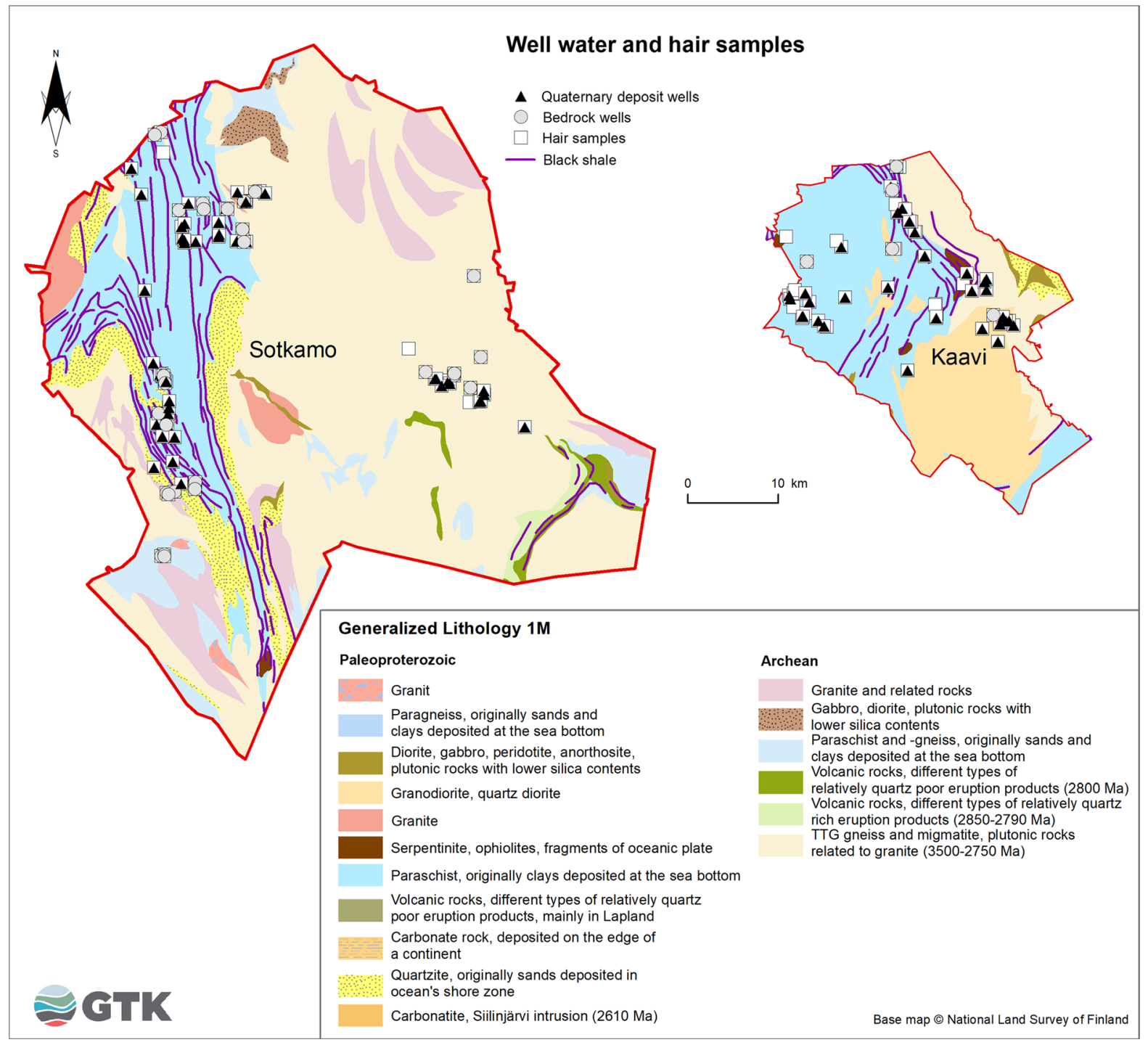

Fig. 3 Location of private houses and voluntary residents providing both human hair and well water samples. The map of the Precambrian bedrock is based on the database of the Geological Survey of Finland (Bedrock of Finland-Digi KP)

back of the head near the scalp using steel scissors. The samples were bound with a thread of cotton and stored in paper envelopes. Dry hair samples (3-50 mg) were treated with a mixture of supra-pure nitric acid and sulphuric acid. Sample mineralization was performed with a microwave digestion system (Loukola-Ruskeeniemi et al., 2003). Hair samples were analysed using ICP-MS/AES with a limit of quantification of $0.05 \mathrm{mg} / \mathrm{kg}$ for $\mathrm{Mn}$ and $0.3 \mathrm{mg} / \mathrm{kg}$ for $\mathrm{Ni}$ in the accredited laboratory of the Geological Survey of Finland. The number of participants for whom both the household well water and hair samples were analysed was 92 (Fig. 2). The mean age of the women and men in this study was, respectively, $57.5 \pm 15.9$ and $51.8 \pm 14.5$ years in Kaavi and $49.6 \pm 17.5$ and $47.7 \pm 14.6$ years in Sotkamo.

\section{Biological samples}

The medical staff of the municipal health centres of Sotkamo and Kaavi collected biological samples. Samples of serum $\mathrm{Zn}, \mathrm{Cu}$, Se and samples of whole blood B-Cd and B-Se were analysed with atomic 
absorption spectrophotometric AAS methods at the University of Kuopio.

The study was approved by the University of Kuopio Research Ethics Committee in accordance with the Helsinki Declaration of 1975 as revised in 1983.

\section{Statistical analyses}

The concentrations of $\mathrm{Mn}$ and $\mathrm{Ni}$ in hair and well water samples, as well as the age, sex and the length of residence of the participants were included in the statistical analyses. Only 92 participants with both household well water and hair analyses were included in the statistical model (Fig. 2). Age was classified into five groups. The normality of the distribution of elements in well water, hair and biological samples, participant age and length of residence was tested using the Kolmogorov-Smirnov test and the ShapiroWilk test. Element concentrations were highly skewed to the right. In the case of skewed distributions and a small number of observations, the nonparametric Mann-Whitney U-test was applied. The KruskallWallis test was used for comparing $\mathrm{Mn}$ and $\mathrm{Ni}$ concentrations in hair samples according to the quartiles of $\mathrm{Mn}$ and $\mathrm{Ni}$ in well waters based on pooled data from the two municipalities. Spearman's correlation coefficients were calculated between untransformed concentrations in hair, water and biological samples and the age and length of residence of the participants separately for the black shale and
Table $1 \mathrm{Mn}$ and $\mathrm{Ni}$ concentrations in samples of hair and household well water from residents of black shale and reference areas in Sotkamo and Kaavi. Data are only included from households in which both hair samples and water from private well were analysed

$\mathrm{SD}=$ standard deviation, LQ = limit of quantification

aMann-Whitney U-test: between black shale and reference areas of Sotkamo; $\mathrm{Ni}$ in water, $p=0.012$

${ }^{\mathrm{b}}$ Mann-Whitney U-test: between reference areas of Sotkamo and Kaavi; Mn in water, $p=0.020$; $\mathrm{Mn}$ in hair, $p=0.041$; Ni in water, $p=0.001$

\begin{tabular}{|c|c|c|c|c|}
\hline Sotkamo & Water Mn $\mu \mathrm{g} / \mathrm{l}$ & Hair $\mathrm{Mn} \mathrm{mg} / \mathrm{kg}$ & Water Ni $\mu \mathrm{g} / \mathrm{l}$ & Hair Ni mg/kg \\
\hline \multicolumn{5}{|c|}{ Black shale area $n=45$} \\
\hline Median & 9.18 & 1.30 & $2.79^{\mathrm{a}}$ & 0.50 \\
\hline Mean $\pm \mathrm{SD}$ & $93.18 \pm 335$ & $2.23 \pm 2.28$ & $4.80 \pm 6.51$ & $0.96 \pm 1.01$ \\
\hline Range & $0.28-1620$ & $0.20-11.10$ & $<$ LQ-24.20 & $<$ LQ-6.00 \\
\hline \multicolumn{5}{|c|}{ Reference area $n=17$} \\
\hline Median & $7,84^{\mathrm{b}}$ & $1.37^{\mathrm{b}}$ & $1.17^{\mathrm{a}, \mathrm{b}}$ & 0.77 \\
\hline Mean $\pm \mathrm{SD}$ & $65.50 \pm 109.65$ & $5.73 \pm 9.16$ & $1.62 \pm 1.62$ & $1.62 \pm 1.99$ \\
\hline Range & $0.94-289$ & $0.21-36.44$ & $<$ LQ-6.17 & $<$ LQ-8.00 \\
\hline \multicolumn{5}{|l|}{ Total $n=62$} \\
\hline Median & 9.18 & 1.34 & 2.58 & 0.5 \\
\hline Mean $\pm \mathrm{SD}$ & $85.59 \pm 290.53$ & $3.19 \pm 5.31$ & $3.93 \pm 5.77$ & $1.14 \pm 1.36$ \\
\hline Range & $0.28-1620$ & $0.20-36.44$ & $<\mathrm{LQ}-24.20$ & $<$ LQ-8.00 \\
\hline Kaavi & Water $\mathrm{Mn} \mu \mathrm{g} / \mathrm{l}$ & Hair Mn mg/kg & Water Ni $\mu \mathrm{g} / 1$ & Hair $\mathrm{Ni} \mathrm{mg/kg}$ \\
\hline \multicolumn{5}{|c|}{ Black shale area $n=19$} \\
\hline Median & 4.48 & 0.91 & 16.00 & 0.89 \\
\hline Mean $\pm \mathrm{SD}$ & $37.64 \pm 110.90$ & $1.75 \pm 2.05$ & $12.91 \pm 13.08$ & $1.72 \pm 2.70$ \\
\hline Range & $0.34-487.00$ & $0.31-7.20$ & $0.16-51.00$ & $<\mathrm{LQ}-12.31$ \\
\hline \multicolumn{5}{|c|}{ Reference area $n=11$} \\
\hline Median & $1.77^{\mathrm{b}}$ & $0.83^{\mathrm{b}}$ & $6.90^{\mathrm{b}}$ & 0.85 \\
\hline Mean \pm SD & $15.15 \pm 41.89$ & $1.56 \pm 2.78$ & $5.73 \pm 2.96$ & $1.10 \pm 0.65$ \\
\hline Range & $0.42-141.00$ & $0.25-9.86$ & $0.18-9.15$ & $0.43-2.58$ \\
\hline \multicolumn{5}{|l|}{ Total $n=30$} \\
\hline Median & 1.94 & 0.90 & 6.90 & 0.87 \\
\hline Mean $\pm \mathrm{SD}$ & $29.40 \pm 91.43$ & $1.68 \pm 2.31$ & $10.28 \pm 11.03$ & $1.49 \pm 2.18$ \\
\hline Range & $0.34-487.00$ & $0.25-9.86$ & $0.16-51.00$ & $<\mathrm{LQ}-12.31$ \\
\hline
\end{tabular}


Table 2 Spearman correlation coefficient matrix for $\mathrm{Mn}$ and $\mathrm{Ni}$ concentrations in water and hair, age, sex, length of residence and smoking years (only in Sotkamo) in the black shale and reference areas of Sotkamo and Kaavi
**Significant at the 0.01 level (2-tailed). *Significant at the 0.05 level (2-tailed).

\begin{tabular}{|c|c|c|c|c|}
\hline Sotkamo black shale area $(n=45)$ & Mn in water & Mn in hair & $\mathrm{Ni}$ in water & $\mathrm{Ni}$ in hair \\
\hline Mn in water & 1 & & & \\
\hline Mn in hair & $0.569^{* *}$ & 1 & & \\
\hline $\mathrm{Ni}$ in water & -0.045 & -0.143 & 1 & \\
\hline $\mathrm{Ni}$ in hair & 0.249 & $0.432^{* *}$ & $0.337^{*}$ & 1 \\
\hline Age & 0.042 & 0.012 & 0.083 & -0.042 \\
\hline Sex & -0.044 & -0.243 & 0.114 & 0.127 \\
\hline Length of residence & -0.115 & -0.022 & -0.216 & -0.172 \\
\hline Smoking years $(\mathrm{n}=19)$ & 0.199 & -0.045 & 0.381 & -0.046 \\
\hline Sotkamo reference area $(n=17)$ & Mn in water & Mn in hair & $\mathrm{Ni}$ in water & $\mathrm{Ni}$ in hair \\
\hline Mn in water & 1 & & & \\
\hline Mn in hair & 0.450 & 1 & & \\
\hline $\mathrm{Ni}$ in water & -0.272 & $-.630^{* *}$ & 1 & \\
\hline $\mathrm{Ni}$ in hair & $-.682^{* *}$ & -0.007 & 0.204 & 1 \\
\hline Age & 0.046 & -0.193 & 0.461 & -0.151 \\
\hline Sex & 0.252 & 0.105 & 0.119 & 0.132 \\
\hline Length of residence & $-.515^{*}$ & -0.255 & 0.085 & 0.251 \\
\hline Kaavi Black shale area $(n=19)$ & Mn in water & Mn in hair & $\mathrm{Ni}$ in water & $\mathrm{Ni}$ in hair \\
\hline Mn in water & 1 & & & \\
\hline Mn in hair & 0.452 & 1 & & \\
\hline $\mathrm{Ni}$ in water & 0.157 & 0.384 & 1 & \\
\hline $\mathrm{Ni}$ in hair & 0.110 & $.577^{* *}$ & $0.686^{* *}$ & 1 \\
\hline Age & 0.106 & 0.186 & -0.142 & -0.157 \\
\hline Sex & 0.250 & 0.259 & 0.441 & -0.020 \\
\hline Length of residence & 0.053 & 0.091 & 0.084 & -0.096 \\
\hline Kaavi reference area $(n=11)$ & Mn in water & Mn in hair & $\mathrm{Ni}$ in water & $\mathrm{Ni}$ in hair \\
\hline Mn in water & 1 & & & \\
\hline Mn in hair & $0.856^{* *}$ & 1 & & \\
\hline $\mathrm{Ni}$ in water & 0.115 & 0.124 & 1 & \\
\hline $\mathrm{Ni}$ in hair & 0.366 & 0.409 & 0.494 & 1 \\
\hline Age & -0.546 & -0.223 & 0.161 & -0.082 \\
\hline Sex & 0.087 & -0.058 & -0.087 & 0 \\
\hline Length of residence & -0.129 & -0.085 & 0.08 & -0.456 \\
\hline
\end{tabular}

reference areas of Kaavi and Sotkamo. The correlation with smoking years (former and current smokers) was only calculated among participants of the black shale area of Sotkamo $(n=19)$. The number of smokers was too small for statistical analysis in the other subgroups. In the case of normally distributed variables, ANOVA was applied. Statistical analyses of the results were conducted using the IBM ${ }^{\circledR}$ SPSS ${ }^{\circledR}$ v.26.0.0 and 28 software and the map presentations using ArcMap 10.3 software.

\section{Results and discussion}

Mn and Ni concentrations in human hair compared with the values in drinking water

We compared $\mathrm{Mn}$ and $\mathrm{Ni}$ concentrations in 92 hair samples with the corresponding household well water concentrations of $\mathrm{Mn}$ and $\mathrm{Ni}$ in the black shale and reference areas of Sotkamo and Kaavi (Figs. 1,2 and 3). The general descriptive statistics for $\mathrm{Mn}$ and $\mathrm{Ni}$ 
concentrations in hair and well water are provided in Table 2. The Finnish national quality requirement for $\mathrm{Ni}$ in drinking water is below $20 \mu \mathrm{g} / \mathrm{l}$. The quality recommendation for $\mathrm{Mn}$, based on technical/aesthetic effects, is below $50 \mu \mathrm{g} / \mathrm{l}$, and the threshold limit is $100 \mu \mathrm{g} / \mathrm{l}$ for small units or households using private wells (STM 1352/2015, STM 401/2001). In the water samples, $9.8 \%$ of $\mathrm{Ni}$ concentrations exceeded the allowable upper limit, while for Mn, $15.5 \%$ of the samples exceeded the national quality recommendation of $50 \mu \mathrm{g} / 1$ and $11.1 \%$ exceeded the threshold limit of $100 \mu \mathrm{g} / \mathrm{l}$. We compared also $\mathrm{Mn}$ and $\mathrm{Ni}$ concentrations in hair of the residents in black shale areas with the reference intervals set by Biolab (2012) and the hair concentrations of residents in the vicinity of mine environments in selected countries (Table 6). In addition, we reported the concentrations of biological samples like serum $\mathrm{Ca}, \mathrm{Zn}, \mathrm{Cu}$, Se and the whole blood $\mathrm{Cd}(\mathrm{B}-\mathrm{Cd})$ and $\mathrm{Se}(\mathrm{B}-\mathrm{Se})$ in the present study (Table 5).

The sample sets

At Sotkamo, the average age of the residents participating in this study was 48.8 years in the black shale area and 49.1 years in the reference area. At Kaavi, the respective average ages were 56.0 and 53.4 years. The length of residence was on average 30.4 years in the black shale area and 22.9 years in the reference area at Sotkamo and 38.7 and 30.9 years, respectively, at Kaavi. The average duration of smoking years among the active smokers was 15.33 years in the black shale area $(n=6)$ at Sotkamo, while the participants from the reference area included only one active smoker with 30 smoking years. At Kaavi, there were no active smokers among the participants. Neither the average age nor the length of residence differs significantly between black shale and reference areas within the municipalities $(p>0.05)$.

At Sotkamo, the median Ni concentration in well water was significantly higher in the black shale area $(2.79 \mu \mathrm{g} / \mathrm{l})$ than in the reference area $(1.17 \mu \mathrm{g} / \mathrm{l})$. At Kaavi, the median concentrations of $\mathrm{Ni}(16.0 \mu \mathrm{g} / \mathrm{l})$ and $\mathrm{Mn}(4.48 \mu \mathrm{g} / \mathrm{l})$ in well water were higher in the black shale than in the reference area, but the difference was not statistically significant (Table 1).

The concentrations of $\mathrm{Mn}$ and $\mathrm{Ni}$ in hair and water did not differ significantly between the black shale areas (Table 1). However, when comparing the reference areas, Mn concentrations in well water $(7.84 \mu \mathrm{g} / \mathrm{l})$ and in hair $(1.37 \mathrm{mg} / \mathrm{kg})$ were significantly higher at Sotkamo, while the Ni concentration in well water $(6.90 \mu \mathrm{g} / \mathrm{l})$ was higher at Kaavi (Table 1).

Correlations between $\mathrm{Mn}$ and $\mathrm{Ni}$ concentrations in hair and water

In the black shale area at Sotkamo, statistically significant correlations were detected between the concentrations of $\mathrm{Mn}$ in hair and well water, $\mathrm{Ni}$ in hair and water, and between $\mathrm{Ni}$ and $\mathrm{Mn}$ in hair (Table 2). No significant correlations were observed between $\mathrm{Mn}$ and $\mathrm{Ni}$ concentrations in hair or well water and participant age, sex, length of residence or smoking years.

In the reference area of Sotkamo, negative correlations were observed between $\mathrm{Ni}$ in hair and $\mathrm{Mn}$ in well water, and between $\mathrm{Ni}$ in well water and $\mathrm{Mn}$ in hair (Table 2). The reason for these negative correlations is unclear. In the black shale area at Kaavi, Ni in hair correlated with $\mathrm{Mn}$ in hair and $\mathrm{Ni}$ in water (Table 2). No significant correlations were observed between other variables. In the reference area at Kaavi, $\mathrm{Mn}$ in hair correlated with $\mathrm{Mn}$ in water $\left(r_{\mathrm{s}}=0.856\right)$. However, this correlation is tentative because of the small number of samples $(n=11)$. No other statistically significant correlations were detected (Table 2). The correlations are presented graphically in Fig. 4.

Pooled data from the municipalities of Sotkamo and Kaavi

In the black shale areas of the pooled data set $(n=64)$, the median concentrations were $8.72 \mu \mathrm{g} / \mathrm{l}$ for $\mathrm{Mn}$ in water, $1.14 \mathrm{mg} / \mathrm{kg}$ for $\mathrm{Mn}$ in hair, $3.52 \mu \mathrm{g} / \mathrm{l}$ for $\mathrm{Ni}$ in water and $0.71 \mathrm{mg} / \mathrm{kg}$ for $\mathrm{Ni}$ in hair. In the reference areas $(n=28)$, the median concentrations were $2.81 \mu \mathrm{g} / 1$ for $\mathrm{Mn}$ in water, $1.25 \mathrm{mg} / \mathrm{kg}$ for $\mathrm{Mn}$ in hair, $2.68 \mu \mathrm{g} / \mathrm{l}$ for $\mathrm{Ni}$ in water and $0.83 \mathrm{mg} / \mathrm{kg}$ for $\mathrm{Ni}$ in hair. We detected no statistically significant differences between $\mathrm{Mn}$ and $\mathrm{Ni}$ concentrations in water or in hair between the black shale and reference areas of the pooled data set. Likewise, $\mathrm{Mn}$ and $\mathrm{Ni}$ concentrations in hair did not differ significantly between men and women in the black shale or reference areas $(\mathrm{Mn}$, $p=0.621 ; \mathrm{Ni}, p=0.655)$. Neither did we observe any difference in $\mathrm{Mn}$ or $\mathrm{Ni}$ concentrations in hair between age groups in the black shale $(\mathrm{Mn}, p=0.778 ; \mathrm{Ni}$, 
Fig. 4 Scatter diagrams of A concentrations of $\mathrm{Mn}$ in hair and water and $\mathbf{B} \mathrm{Ni}$ in hair and water in the black shale area at Sotkamo $(\mathrm{n}=45), \mathbf{C}$ concentrations of $\mathrm{Mn}$ in hair and $\mathrm{Ni}$ in water and $\mathbf{D} \mathrm{Ni}$ in hair and $\mathrm{Mn}$ in water in the reference area at Sotkamo $(n=17)$, and E concentrations of $\mathrm{Ni}$ and $\mathrm{Mn}$ in hair, and $\mathbf{F ~ N i}$ in hair and water in the black shale area at Kaavi $(n=19)$. The study areas are rural and pristine, and sparsely populated

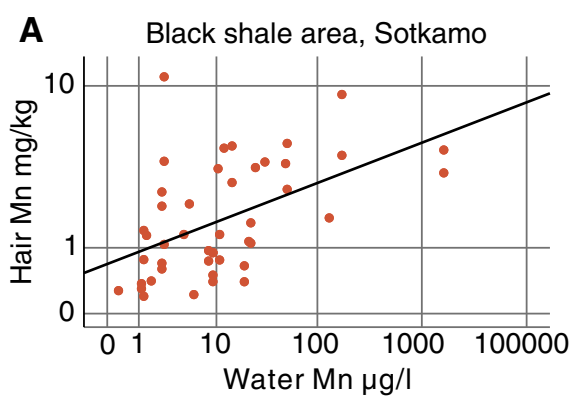

B Black shale area, Sotkamo
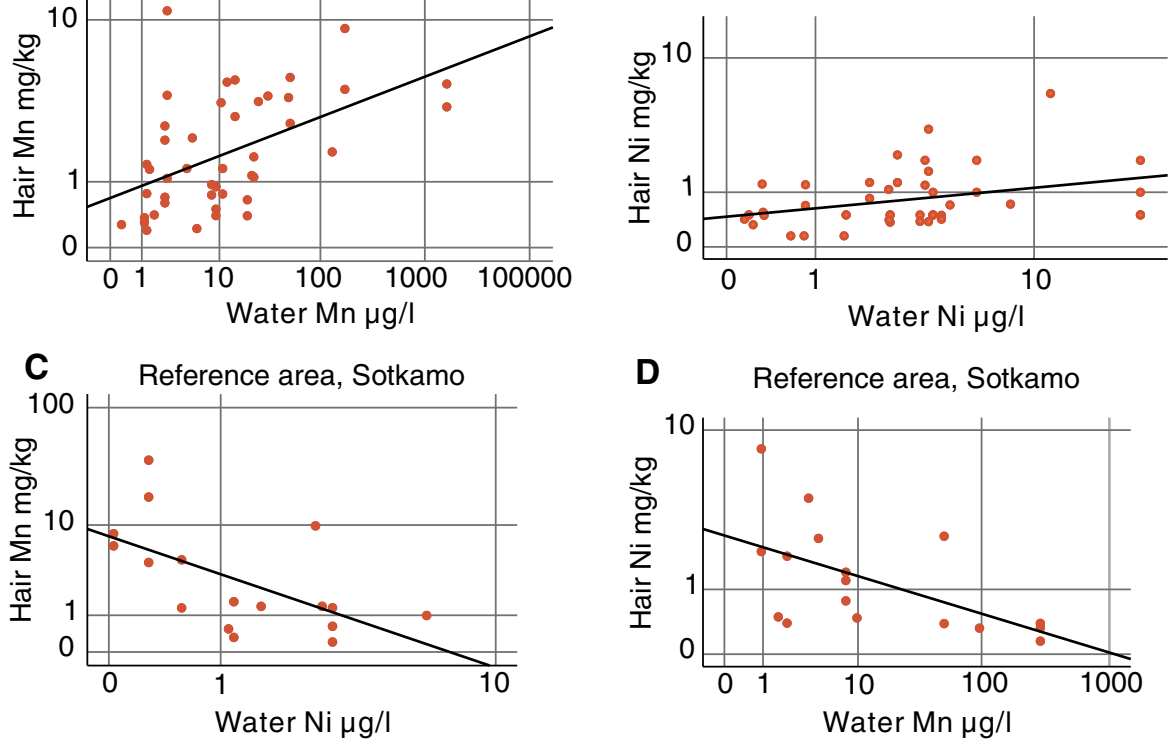

D Reference area, Sotkamo
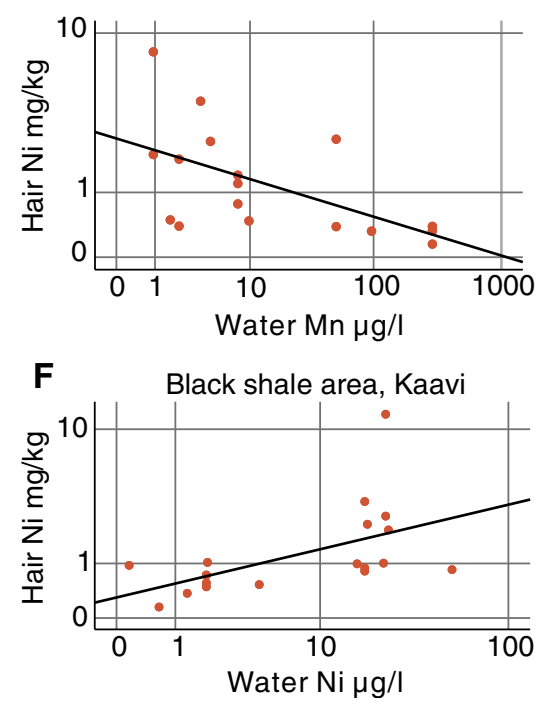

$p=0.841)$ or reference areas $(\mathrm{Mn}, p=0.507 ; \mathrm{Ni}$, $p=0.362$ ).

In the pooled black shale areas, $\mathrm{Mn}$ in hair correlated with $\mathrm{Mn}$ in water $\left(r_{\mathrm{s}}=0.578, p<0.01\right)$, $\mathrm{Ni}$ in hair with $\mathrm{Ni}$ in water $\left(r_{\mathrm{s}}=0.459, p<0.01\right)$ and $\mathrm{Mn}$ in hair with Ni in hair $\left(\mathrm{r}_{\mathrm{s}}=0.400, p<0.01\right)$. In the pooled reference areas, $\mathrm{Mn}$ in hair correlated positively with $\mathrm{Mn}$ in water $\left(r_{\mathrm{s}}=0.640, p<0.01\right)$ and negatively with $\mathrm{Ni}$ in water $\left(r_{\mathrm{s}}=-0.409, p=0.031\right)$.

In the pooled data for the black shale areas of the two municipalities, the median Mn concentrations in hair increased as a function of Mn concentrations in well water, being $3.94 \mathrm{mg} / \mathrm{kg}$ in the 4th quartile of $\mathrm{Mn},>22.40 \mu \mathrm{g} / \mathrm{l}(p<0.001)$. Likewise, the median $\mathrm{Ni}$ concentrations in hair increased as a function of the $\mathrm{Ni}$ concentrations in well water, being $1.00 \mathrm{mg} / \mathrm{kg}$ in the 4 th quartile of $\mathrm{Ni},>7.62 \mu \mathrm{g} / \mathrm{l} \quad(p=0.001)$ (Table 3).

In the pooled data for the reference areas, the median $\mathrm{Mn}$ concentrations in hair increased as a function of the Mn concentrations in well water, being $8.33 \mathrm{mg} / \mathrm{kg}$ in the 4 th quartile of $\mathrm{Mn},>41.18 \mu \mathrm{g} / \mathrm{l}$ $(p=0.004)$. The highest $\mathrm{Ni}$ concentration in hair, $1.20 \mathrm{mg} / \mathrm{kg}$, was found in the $3 \mathrm{rd}$ quartile of $\mathrm{Ni}$ in well water, 2.69-5.77 $\mu \mathrm{g} / \mathrm{l}(p=0.525)$ (Table 3). Medians of $\mathrm{Mn}$ in hair were higher than the upper limit of reference interval, $2.00 \mathrm{mg} / \mathrm{kg}$ for $\mathrm{Mn}$, set by Biolab (2012) in the 4th quartile of Mn in well water in both, black shale and reference areas. Medians of $\mathrm{Ni}$ in hair did not exceed the threshold value $>1.4 \mathrm{mg} / \mathrm{kg}$ for $\mathrm{Ni}$ in hair (Table 3).

$\mathrm{Mn}$ and Ni concentrations in Quaternary deposit wells and drilled bedrock wells

We compared $\mathrm{Mn}$ and $\mathrm{Ni}$ concentrations in hair and water among users of two different well types. In rural areas of Finland, water supplies consist of wells in Quaternary deposits (springs, captured springs and dug wells) and wells drilled into bedrock. General 
Table $3 \mathrm{Mn}$ and Ni concentrations in hair samples according to quartiles (Q1-Q4) of Mn and Ni concentrations in well water in the pooled data for the black shale and reference areas of the two municipalities, Sotkamo and Kaavi

\begin{tabular}{|c|c|c|c|c|c|}
\hline \multirow{2}{*}{$\begin{array}{l}\text { Black shale area. } \mathrm{Mn} \text { in well water } \\
(\mu \mathrm{g} / \mathrm{l}) \\
(\mathrm{Q} 1)<2.0\end{array}$} & \multicolumn{2}{|c|}{ Mn in hair $(\mathrm{mg} / \mathrm{kg})$} & \multirow{2}{*}{$\begin{array}{l}\begin{array}{l}\text { Ni in well water } \\
(\mu \mathrm{g} / \mathrm{l})\end{array} \\
<1.54\end{array}$} & \multicolumn{2}{|c|}{$\mathrm{Ni}$ in hair $(\mathrm{mg} / \mathrm{kg})$} \\
\hline & Median & 0.60 & & Median & 0.50 \\
\hline & Mean & 0.70 & & Mean & 0.52 \\
\hline & SD & 0.41 & & SD & 0.33 \\
\hline & Range & $0.20-1.40$ & & Range & $<\mathrm{LQ}-1.2$ \\
\hline & $\mathrm{N}$ & 16 & & $\mathrm{~N}$ & 17 \\
\hline \multirow[t]{5}{*}{ (Q2) 2.01-8.72 } & Median & 1.01 & $1.55-3.52$ & Median & 0.64 \\
\hline & Mean & 1.91 & & Mean & 0.80 \\
\hline & $\mathrm{SD}$ & 2.66 & & SD & 0.48 \\
\hline & Range & $0.22-11.10$ & & Range & $0.4-2.2$ \\
\hline & $\mathrm{N}$ & 16 & & $\mathrm{~N}$ & 16 \\
\hline \multirow[t]{5}{*}{ (Q3) 8.73-22.40 } & Median & 1.14 & $3.53-7.62$ & Median & 0.70 \\
\hline & Mean & 1.74 & & Mean & 1.01 \\
\hline & SD & 1.44 & & SD & 0.86 \\
\hline & Range & $0.40-4.84$ & & Range & $0.4-3.5$ \\
\hline & $\mathrm{N}$ & 17 & & $\mathrm{~N}$ & 16 \\
\hline \multirow[t]{5}{*}{$(\mathrm{Q} 4)>22.40$} & Median & 3.94 & $>7.62$ & Median & 1.00 \\
\hline & Mean & 4.17 & & Mean & 2.37 \\
\hline & SD & 2.22 & & SD & 3.01 \\
\hline & Range & $0.71-9.94$ & & Range & $0.5-12.3$ \\
\hline & $\mathrm{N}$ & 15 & & $\mathrm{~N}$ & 16 \\
\hline \multirow[t]{5}{*}{ Total } & Median & 1.14 & Total & Median & 0.71 \\
\hline & Mean & 2.09 & & Mean & 1.19 \\
\hline & SD & 2.21 & & SD & 1.71 \\
\hline & Range & $0.20-11.10$ & & Range & $<$ LQ-12.3 \\
\hline & $\mathrm{N}$ & 64 & & $\mathrm{~N}$ & 64 \\
\hline$p$-value & & $<0.001^{\mathrm{a}}$ & & & $0.001^{\mathrm{b}}$ \\
\hline $\begin{array}{l}\text { Reference area. } M n \text { in well water } \\
(\mu \mathrm{g} / \mathrm{l})\end{array}$ & \multicolumn{2}{|c|}{ Mn in hair $(\mathrm{mg} / \mathrm{kg})$} & $\begin{array}{l}\mathrm{Ni} \text { in well water } \\
(\mu \mathrm{g} / \mathrm{l})\end{array}$ & \multicolumn{2}{|c|}{$\mathrm{Ni}$ in hair $(\mathrm{mg} / \mathrm{kg})$} \\
\hline \multirow[t]{5}{*}{$(\mathrm{Q} 1)<1.67$} & Median & 0.44 & $<0.57$ & Median & 0.47 \\
\hline & Mean & 1.13 & & Mean & 1.79 \\
\hline & SD & 1.61 & & SD & 2.66 \\
\hline & Range & $0.25-4.70$ & & Range & $<\mathrm{LQ}-8.0$ \\
\hline & $\mathrm{N}$ & 7 & & $\mathrm{~N}$ & 8 \\
\hline \multirow[t]{5}{*}{ (Q2) 1.68-2.81 } & Median & 0.93 & $0.58-2.68$ & Median & 0.46 \\
\hline & Mean & 0.91 & & Mean & 1.30 \\
\hline & SD & 0.43 & & SD & 1.58 \\
\hline & Range & $0.32-1.58$ & & Range & $0.3-4.3$ \\
\hline & $\mathrm{N}$ & 7 & & $\mathrm{~N}$ & 6 \\
\hline \multirow[t]{5}{*}{ (Q3) 2.82-41.18 } & Median & 1.30 & $2.69-5.77$ & Median & 1.20 \\
\hline & Mean & 2.26 & & Mean & 1.40 \\
\hline & SD & 3.37 & & SD & 0.82 \\
\hline & Range & $0.21-9.83$ & & Range & $0.6-2.6$ \\
\hline & $\mathrm{N}$ & 7 & & $\mathrm{~N}$ & 7 \\
\hline
\end{tabular}


Table 3 continued

\begin{tabular}{|c|c|c|c|c|c|}
\hline \multirow{2}{*}{$\begin{array}{l}\text { Reference area. } \mathrm{Mn} \text { in well water } \\
(\mu \mathrm{g} / \mathrm{l}) \\
(\mathrm{Q} 4)>41.18\end{array}$} & \multicolumn{2}{|c|}{ Mn in hair $(\mathrm{mg} / \mathrm{kg})$} & \multirow{2}{*}{$\begin{array}{l}\text { Ni in well water } \\
(\mu \mathrm{g} / \mathrm{l}) \\
>>5.77\end{array}$} & \multicolumn{2}{|c|}{$\mathrm{Ni}$ in hair $(\mathrm{mg} / \mathrm{kg})$} \\
\hline & Median & 8.33 & & Median & 1.10 \\
\hline & Mean & 12.07 & & Mean & 1.08 \\
\hline & SD & 11.9 & & SD & 0.46 \\
\hline & Range & $1.37-36.44$ & & Range & $0.5-1.7$ \\
\hline & $\mathrm{N}$ & 7 & & $\mathrm{~N}$ & 7 \\
\hline \multirow[t]{6}{*}{ Total } & Median & 1.25 & Total & & \\
\hline & Median & 0.83 & & & \\
\hline & Mean & 4.09 & & Mean & 1.41 \\
\hline & SD & 7.54 & & SD & 1.60 \\
\hline & Range & $0.21-36.44$ & & Range & $<\mathrm{LQ}-8.0$ \\
\hline & $\mathrm{N}$ & 28 & & $\mathrm{~N}$ & 28 \\
\hline$p$-value & & $0.004^{\mathrm{a}}$ & & & $0.525^{\mathrm{b}}$ \\
\hline
\end{tabular}

$S D$, standard deviation, $L Q=$ limit of quantification

${ }^{a}$ Kruskall-Wallis test between concentrations of $\mathrm{Mn}$ in hair according to quartiles of Mn concentrations in well water

${ }^{\mathrm{b}}$ Kruskall-Wallis test between concentrations of $\mathrm{Ni}$ in hair according to quartiles of $\mathrm{Ni}$ concentrations in well water

statistics on $\mathrm{Mn}$ and $\mathrm{Ni}$ concentrations in hair and water from both well types are presented in Table 4.

Comparing the black shale and reference areas, the median concentration of Mn was higher in water taken from both Quaternary deposit wells $(p=0.018)$ and bedrock wells $(p>0.05)$ in the black shale areas. Comparing $\mathrm{Mn}$ and $\mathrm{Ni}$ concentrations in water and hair between users of bedrock well water and Quaternary deposit well water in the black shale areas, the Mn concentration in water was significantly higher $(p=0.002)$ and that in hair nonsignificantly higher $(p=0.111)$ among the participants using bedrock well water. Higher Ni concentrations in water $(p<0.001)$ and hair $\mathrm{Ni}(p=0.007)$ were recorded among the participants using Quaternary deposit well water.

In the reference areas, higher median values of $\mathrm{Mn}$ in water $(p=0.006)$ and in hair $(p=0.047)$ were detected among the users of bedrock well water, whereas Ni concentrations were higher in Quaternary deposit well water $(p=0.003)$.

In the black shale areas, the Mn concentrations in well water exceeded the Finnish threshold limit of $100 \mu \mathrm{g} / \mathrm{l}$ for $\mathrm{Mn}$ in three bedrock wells (130-172 $\mu \mathrm{g} / \mathrm{l})$ and three Quaternary deposit wells (487-1620 $\mu \mathrm{g} / \mathrm{l})$. The Ni concentrations in well water were below the national quality requirement for $\mathrm{Ni}$ in all bedrock wells (STM 2001, 2015). Higher Ni concentrations were recorded in nine water samples from Quaternary deposit wells in the black shale areas. In one of the samples, the Ni concentration was two and a half times higher $(51 \mu \mathrm{g} / \mathrm{l})$ than the national quality requirement of $20 \mu \mathrm{g} / \mathrm{l}$ and in eight samples slightly exceeded this regulation for Ni (concentrations 22.20-24.20 $\mu \mathrm{g} / \mathrm{l}$ ). In the reference areas, $\mathrm{Mn}$ concentrations in water exceeding the threshold limit were found in four bedrock wells (141-289 $\mu \mathrm{g} / \mathrm{l})$.

Median concentration of $\mathrm{Mn}$ in hair exceeded the upper limit of reference interval (Biolab 2012) only in bedrock well water users in black shale area (Table 4).

In Finland as a whole, the median Mn concentration is $4.36 \mu \mathrm{g} / \mathrm{l}$ in dug wells and $16.3 \mu \mathrm{g} / \mathrm{l}$ in bedrock wells, and the respective concentrations for $\mathrm{Ni}$ are $0.84 \mu \mathrm{g} / \mathrm{l}$ and $0.6 \mu \mathrm{g} / \mathrm{l}$ (Lahermo et al., 2002). In the black shale areas of this study, the Mn concentration in bedrock well water, $24.9 \mu \mathrm{g} / \mathrm{l}$, was higher than the average Mn concentration in the water of bedrock wells for the whole country. In the Quaternary deposit well waters in both black shale and reference areas, the $\mathrm{Ni}$ concentrations were higher than those in well water in Finland on average (Table 4).

Pooled data of biological samples from the municipalities of Sotkamo and Kaavi

Concentrations of the biological samples are presented in Table 5. 
Table 4 Median values and ranges (2\%-max) for $\mathrm{Mn}$ and $\mathrm{Ni}$ concentrations in hair and water from Quaternary deposit and bedrock wells in the black shale and reference areas of this study (pooled) and median Mn and Ni concentrations in well water for the whole of Finland (Lahermo et al., 2002)

\begin{tabular}{|c|c|c|c|c|c|c|}
\hline & \multicolumn{2}{|l|}{ Black shale area } & \multicolumn{2}{|l|}{ Reference area } & \multicolumn{2}{|c|}{ Well water in Finland ${ }^{\mathrm{d}}$} \\
\hline & $\begin{array}{l}\text { Quaternary deposit } \\
\text { wells }(n=49)\end{array}$ & $\begin{array}{l}\text { Bedrock } \\
\text { wells } \\
(n=15)\end{array}$ & $\begin{array}{l}\text { Quaternary deposit } \\
\text { wells }(n=11)\end{array}$ & $\begin{array}{l}\text { Bedrock } \\
\text { wells } \\
(n=17)\end{array}$ & $\begin{array}{l}\text { Quaternary deposit } \\
\text { wells }(n=739)\end{array}$ & $\begin{array}{l}\text { Bedrock wells } \\
(n=263)\end{array}$ \\
\hline \multicolumn{7}{|l|}{$\begin{array}{l}\text { Water Mn } \\
\mu \mathrm{g} / 1\end{array}$} \\
\hline Median & $5.07^{\mathrm{a}, \mathrm{b}}$ & $24.9^{\mathrm{b}}$ & $1.77^{\mathrm{a}, \mathrm{c}}$ & $7.84^{\mathrm{c}}$ & 4.36 & 16.3 \\
\hline $\begin{array}{l}2 \%- \\
\text { maximum }\end{array}$ & $0.34-1620$ & $0.28-172$ & $0.42-12.90$ & $0.94-289$ & $0.1-5330$ & $0.2-4140$ \\
\hline \multicolumn{7}{|l|}{$\begin{array}{c}\text { Hair Mn } \\
\mathrm{mg} / \mathrm{kg}\end{array}$} \\
\hline Median & 0.94 & 2.03 & $0.83^{\mathrm{c}}$ & $1.37^{\mathrm{c}}$ & & \\
\hline $\begin{array}{l}2 \%- \\
\text { maximum }\end{array}$ & $0.20-11.1$ & $0.27-9.04$ & $0.25-9.83$ & $0.21-36.44$ & & \\
\hline \multicolumn{7}{|l|}{$\begin{array}{c}\text { Water Ni } \\
\mu \mathrm{g} / 1\end{array}$} \\
\hline Median & $3.83^{\mathrm{b}}$ & $0.65^{\mathrm{b}}$ & $4.55^{\mathrm{c}}$ & $1.17^{\mathrm{c}}$ & 0.84 & 0.595 \\
\hline $\begin{array}{l}2 \%- \\
\text { maximum }\end{array}$ & $0.32-51.0$ & $0.15-8.15$ & $1.10-8.87$ & $0.03-9.15$ & $0.06-277$ & $<0.06-67.50$ \\
\hline \multicolumn{7}{|l|}{$\begin{array}{r}\text { Hair Ni } \\
\mathrm{mg} / \mathrm{kg}\end{array}$} \\
\hline Median & $0.85^{\mathrm{b}}$ & $0.49^{\mathrm{b}}$ & 0.86 & 0.77 & & \\
\hline $\begin{array}{l}2 \%- \\
\text { maximum }\end{array}$ & $0.15-12.3$ & $0.15-2.2$ & $0.44-4.3$ & $0.15-8.0$ & & \\
\hline
\end{tabular}

${ }^{a}$ Mann-Whitney U-test: difference in Mn concentrations in water between Quaternary deposit wells of black shale and reference areas, $p=0.018$

${ }^{\mathrm{b}}$ Mann-Whitney U-test: difference in Mn and Ni concentrations between Quaternary deposit and bedrock wells in the black shale areas, $\mathrm{Mn}$ in water $p=0.002, \mathrm{Ni}$ in water $p<0.001$, Ni in hair $p=0.007$

${ }^{\mathrm{c}}$ Mann-Whitney U-test: difference in Mn and Ni concentrations between Quaternary deposit and bedrock wells of the reference areas, Mn in water $p=0.006, \mathrm{Mn}$ in hair $p=0.047$, Ni in water $p=0.003$

${ }^{\mathrm{d}}$ Lahermo et al. (2002)

Calcium. Ca absorption varies inversely with dietary $\mathrm{Ca}$ intake. Absorption of $\mathrm{Ca}$ from food is about $45 \%$ at intakes of $200 \mathrm{mg} / \mathrm{day}$, but only $15 \%$ when intakes are higher than 2,000 mg/day (Fairweather-Tait \& Teucher, 2002). Fractional absorption gradually declines with age (Heaney et al., 1989). A normal range for blood calcium level is 8.6 to $10.3 \mathrm{mg} / \mathrm{dl}$ (86-103 mg/l) (UCLA Health, 2021). Median of serum $\mathrm{Ca}$ concentration was higher in the reference area than in the black shale area. Serum $\mathrm{Ca}$ did not correlate with $\mathrm{Ca}$ in hair $\left(r_{\mathrm{s}}=0.100\right.$, $p=0.346) \mathrm{Ca}$ in water $\left(r_{\mathrm{s}}=0.143, p=0.176\right)$. Ca in hair correlated with $\mathrm{Ca}$ in water $\left(r_{\mathrm{s}}=0.478\right.$, $p<0.01)$.
Zinc. $\mathrm{Zn}$ is an essential micronutrient for humans. The levels of $\mathrm{Zn}$ in healthy adults are approximately $1 \mathrm{mg} / \mathrm{l}$ in serum (ATSDR 2005b). The concentration of serum $\mathrm{Zn}$ did not vary between the black shale and reference areas $(p=0.173)$. Serum $\mathrm{Zn}$ concentrations did not correlate with $\mathrm{Zn}$ in hair $\left(r_{\mathrm{s}}=-0.011\right.$, $p=0.919)$ or well water $\left(r_{\mathrm{s}}=-0.157, p=0.134\right)$ either.

Copper. The general population could exposure to copper via food and drinking water, copper especially from water distribution systems. Among healthy persons, the serum $\mathrm{Cu}$ concentrations range up to approximately $1.5 \mathrm{mg} / \mathrm{l}$ (Barceloux DG 1999). The serum $\mathrm{Cu}$ concentration did not vary between 
Table 5 Serum $\mathrm{Zn}, \mathrm{Cu}, \mathrm{Se}$, and whole blood $\mathrm{Cd}$ and $\mathrm{Se}$ concentrations in the pooled black shale and reference areas

\begin{tabular}{|c|c|c|c|c|c|c|c|c|c|}
\hline \multicolumn{5}{|l|}{ Black shale areas } & \multicolumn{5}{|c|}{ Reference areas } \\
\hline Concentration & Median & Mean SD & Range & $n$ & Median & Mean SD & Range & $n$ & $p$-value ${ }^{a}$ \\
\hline Serum Ca mg/l & 91.40 & $91.55 \pm 4.12$ & 78.3-102.6 & 103 & 93.6 & $93.53 \pm 3.85$ & $85.50-103.3$ & 82 & $p<0.001^{b}$ \\
\hline Serum Zn mg/l & 0.82 & $0.86 \pm 0.16$ & $0.55-1.53$ & 104 & 0.87 & $0.87 \pm 0.12$ & $0.61-1.21$ & 82 & $p=0.122$ \\
\hline Serum $\mathrm{Cu} \mathrm{mg} / \mathrm{l}$ & 1.15 & $1.20 \pm 0.26$ & $0.79-2.28$ & 104 & 1.15 & $1.17 \pm 0.24$ & $0.60-1.90$ & 82 & $p=0.610$ \\
\hline Serum Se $\mu \mathrm{g} / 1$ & 92.25 & $91.53 \pm 10.53$ & $69.50-113.0$ & 104 & 91.50 & $92.26 \pm 15.18$ & $48.50-148.0$ & 80 & $p=0.975$ \\
\hline${ }^{\mathrm{c}} \mathrm{B}-\mathrm{Se} \mu \mathrm{g} / \mathrm{l}$ & 102.00 & $101.47 \pm 10.73$ & $76.00-125.0$ & 97 & 98.50 & $101.12 \pm 21.53$ & $67.50-210.0$ & 82 & $p=0.180$ \\
\hline${ }^{\mathrm{c}} \mathrm{B}-\mathrm{Cd} \mu \mathrm{g} / \mathrm{l}$ & 0.25 & $0.37 \pm 0.42$ & $0-2.73$ & 98 & 0.21 & $0.41 \pm 0.73$ & $0.03-5.00$ & 82 & $p=0.425$ \\
\hline
\end{tabular}

${ }^{a}$ Mann-Whitney U-test: between black shale and reference areas (pooled data of Sotkamo and Kaavi)

${ }^{\mathrm{b}} \mathrm{T}$-test: between black shale and reference areas (pooled data of Sotkamo and Kaavi)

${ }^{\mathrm{c}} \mathrm{B}-\mathrm{Se}=$ whole blood $\mathrm{Se},{ }^{\mathrm{b}} \mathrm{B}-\mathrm{Cd}=$ whole blood $\mathrm{Cd}$

the black shale and reference areas. Serum $\mathrm{Cu}$ did not correlate with $\mathrm{Cu}$ in hair $\left(r_{\mathrm{s}}=-0.052, p=0.619\right)$ or well water $\left(r_{\mathrm{s}}=-0.133, p=0.207\right) . \mathrm{Cu}$ in hair correlated with well water $\mathrm{Cu} \quad\left(r_{\mathrm{s}}=0.432\right.$, $p=<0.01)$.

Selenium. Se is an essential micronutrient needed by the body in small amounts. It is necessary for the function of enzymes involved in antioxidant defence, thyroid hormone metabolism and redox control of intracellular reactions (ATSDR 2003). Short-term oral exposure to high concentrations of Se may cause nausea, vomiting and diarrhoea, and long-term exposure to Se may cause selenosis, a disease characterized by hair loss (ATSDR 2003). In a study in US, the geometric mean concentration of Se in serum of all ages was approximately $125 \mu \mathrm{g} / \mathrm{l}$ (ATSDR 2003). In the present study, the geometric mean of serum Se was $90,92 \mu \mathrm{g} / \mathrm{l}$ in the black shale areas and $91.02 \mu \mathrm{g} / \mathrm{l}$ in the reference areas. Serum Se $(p=0.975)$ or Se in whole blood did not vary between the black shale and reference areas. Serum Se correlated with whole blood Se, $r_{\mathrm{s}}=0.549, p=<0.01$ and Se concentration in hair correlated slightly with Se in water, $r_{\mathrm{s}}=0.260$, $p=0.012$. Serum Se and whole blood Se did not correlate with Se in hair $\left(r_{\mathrm{s}}=-0.038, p=722\right.$, $r_{\mathrm{s}}=-0.041, p=0.706$, respectively) or Se in well water $\left(r_{\mathrm{s}}=0.160, p=0.129, r_{\mathrm{s}}=0.084, p=0.442\right.$, respectively).

Cadmium. Kidney and bone are the most sensitive targets following oral exposure and lung following inhalation exposure. Inhalation is the predominant route of exposure to $\mathrm{Cd}$ for the smoking population and oral exposure for the non-smoking general population (ATSDR, 2008). The overall median blood cadmium concentration was $0.27 \mu \mathrm{g} / 1$ in men and $0.33 \mu \mathrm{g} / \mathrm{l}$ in women among the American adult population (Zeng et al., 2021). Smoking may cause significant increases in blood cadmium (B-Cd) levels (Jarup et al., 1998). A total number of current smokers was 26 in the present study. In the black shale areas, the median $\mathrm{Cd}$ concentration in blood among current smokers was $0.92 \mu \mathrm{g} / \mathrm{l}$ in men $(n=8)$ and $0.45 \mu \mathrm{g} / \mathrm{l}$ in women $(n=5)$. Among non-smokers, the medians were $0.23 \mu \mathrm{g} / \mathrm{l}$ in men $(n=39)$ and $0.24 \mu \mathrm{g} / \mathrm{l}$ in women $(n=46)$. In reference area, the median $\mathrm{Cd}$ concentration in blood among current smokers was $0.97 \mu \mathrm{g} / \mathrm{l}$ in men $(n=10)$ and $0.83 \mu \mathrm{g} / \mathrm{l}$ in women $(n=3)$. Among non-smokers, medians were $0.20 \mu \mathrm{g} / \mathrm{l}$ $(n=27)$ in men and 0.19 in women $(n=41)$. We didn't find any correlation between $\mathrm{Cd}$ concentration in whole blood and $\mathrm{Cd}$ concentrations in hair $\left(r_{\mathrm{s}}=0.048, p=0.723\right)$ or well water $\left(r_{\mathrm{s}}=-0.050\right.$, $p=0.711)$ in black shale areas or in reference areas $\left(r_{\mathrm{s}}=0.094, p=0.633, r_{\mathrm{s}}=0.127, p=0.518\right)$, respectively. The whole blood $\mathrm{Cd}$ concentrations did not vary between the black shale and reference areas.

Mn and Ni concentrations in human hair in the vicinity of mine environments in different countries

A summary of the mean values of $\mathrm{Mn}$ and $\mathrm{Ni}$ concentrations in human hair $(\mathrm{mg} / \mathrm{kg})$ in the vicinity 
Table $6 \mathrm{Mn}$ and $\mathrm{Ni}(\mathrm{mg} / \mathrm{kg})$ concentrations in hair in the vicinity of mining areas in the selected countries

\begin{tabular}{|c|c|c|c|c|c|c|c|c|}
\hline Country & $n$ & Age & $\begin{array}{l}\text { Mn } \\
\text { median }\end{array}$ & Mn mean & Mn range & $\begin{array}{l}\mathrm{Ni} \\
\text { median }\end{array}$ & Ni mean & Ni range \\
\hline Portugal $^{a}$ & 39 & $15-46$ & & & & & & \\
\hline S.Domingos & 20 & & & $2.61 \pm 1.04$ & $0.022-19.62$ & & & \\
\hline Corte do Pinto & 9 & & & $2.99 \pm 1.07$ & $0.056-12.48$ & & & \\
\hline Santana de Cambas & 10 & & & $10.81 \pm 3.42$ & $0.023-35.48$ & & & \\
\hline Zambia $^{b}$ & na & $11-40$ & & & & & & \\
\hline Mugala & & & & $16.3 \pm 2.3$ & $3.9-44.0$ & & $1.3 \pm 0.23$ & $0.21-6.06$ \\
\hline Italy $^{c}$ & & $11-14$ & & & & & & \\
\hline $\begin{array}{l}\text { Iglesias and } \\
\text { Sant'Antioco, Sardinia }\end{array}$ & & & 0.31 & & & 0.22 & & \\
\hline Russia ${ }^{d}$ & 128 & $7-14$ & & & & & & \\
\hline Ishmurzino & 33 & & 1.09 & $1.43 \pm 0.51$ & $0.61-3.43$ & 0.18 & $0.24 \pm 0.07$ & $0.15-0.50$ \\
\hline Semenovsk & 30 & & 1.07 & $1.21 \pm 0.34$ & $0.31-2.65$ & 0.28 & $0.30 \pm 0.06$ & $0.17-0.47$ \\
\hline Tubinsk & 65 & & 2.34 & $2.38 \pm 0.20$ & $1.64-3.21$ & 0.27 & $0.45 \pm 0.17$ & $0.11-2.06$ \\
\hline Finland $^{e}$ & 64 & $15-85$ & & & & & & \\
\hline Sotkamo black shale & 45 & $15-84$ & 1.30 & $2.23 \pm 2.28$ & $0.20-11.10$ & 0.50 & $0.96 \pm 1.01$ & $\begin{array}{l}<\mathrm{LQ}- \\
6.00\end{array}$ \\
\hline Kaavi black shale & 19 & $28-85$ & 0.91 & $1.75 \pm 2.05$ & $0.31-7.20$ & 0.89 & $1.72 \pm 2.70$ & $\begin{array}{r}<\mathrm{LQ}- \\
12.31\end{array}$ \\
\hline Reference intervat $t^{f}$ & $\begin{array}{l}\text { Mn 0.20-2.00, } \\
\quad \mathrm{Ni}<1.4\end{array}$ & & & & & & & \\
\hline
\end{tabular}

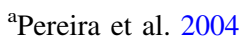

${ }^{\mathrm{b}}$ Nakaona et al. 2020

${ }^{\mathrm{c}}$ Tamburo et al. 2016

${ }^{\mathrm{d}}$ Semenova et al. 2018

epresent study

${ }^{\mathrm{f}}$ Biolab Medical Unit 2012

of mining areas in different countries is presented in Table 6

The sampling area of a Portuguese study consists of the neighbourhood of the S.Domingos mine, an abandoned cupric pyrite mine located in the Southeast Alentejo, and two nearby villages, Corte do Pinto, located north of the mine, and Santana de Cambas, south of the mine (Pereira et al., 2004). The mean concentrations of $\mathrm{Mn}$ in hair are in line with those in the Sotkamo black shale area except for those among residents of the Santana de Cambas where Mn concentrations are higher (Table 6). Maximum concentrations of $\mathrm{Mn}$ are much higher than those in our study. The highest average concentration of $\mathrm{Mn}$ in hair is recorded in inhabitants from the Corte do Pinto and Santana de Cambas localities, where the highest concentration of $\mathrm{Mn}$ is recorded in the soil (Pereira et al., 2004). The results suggest that the population of the S.Domingos mine area and neighbour localities may be exposed to $\mathrm{Mn}$. There is no evidence that water supplies are a potential source of heavy metals. The group that reported to consume only bottled water present the highest concentrations of $\mathrm{Mn}$ in the scalp hair (Pereira et al., 2016).

The study area of Zambia, Mugala village, is situated in Kitwe West on the Copperbelt Province of Zambia. It is located near the Mopani tailings dump site. Consumption of vegetables grown in the contaminated areas of the Copperbelt and the large-scale mining operations have affected the health of residents (Nakaona et al., 2020). The mean and maximum concentrations of $\mathrm{Mn}$ in hair are higher while $\mathrm{Ni}$ concentrations are lower than those in our study. In the Zambian study, the high $\mathrm{Ni}$ dietary intake from 
drinking water seems to accumulate in toenails while $\mathrm{Mn}$ is highly accumulated in hair (Nakaona et al., 2020).

In the Italian study, Iglesias and Sant'Antioco, the long-lasting polymetallic mining areas, locate in southwestern Sardinia. The outcrops of sulphide and oxide ores characterize the district with high concentrations of metals and metalloids (Tamburo et al., 2016). The median concentrations of $\mathrm{Mn}$ and $\mathrm{Ni}$ in hair are lower than those in the black shale areas in Finland. The authors suggest that $\mathrm{Ni}$ in hair shows 2.5fold higher concentration in female hair (Tamburo et al., 2016).

The Russian study area is in the rural settlements on the territory of the Baymaksky District of the Republic of Bashkortostan (Russia) located in the vicinity of abandoned mines (Semenova et al., 2018). The median concentrations of $\mathrm{Mn}$ are slightly higher in the Sotkamo black shale area than those reported in the Russian study except for hair samples from Tubinsk where Mn concentrations are higher than in our study. The median and maximum values of $\mathrm{Ni}$ are higher in our study compared to those reported in the Russian study (Table 6).

Mean values of the $\mathrm{Mn}$ concentrations in hair exceed the upper limit of reference interval $2.0 \mu \mathrm{g} / \mathrm{kg}$ (Biolab Medical Unit, 2012) in all study areas listed in Table 6 except in Ishmurzino and Semenovsk in Russia and the black shale area in Kaavi. In Tubinsk, the median concentration of Mn exceeds the maximum reference value. Maximum of Mn concentrations exceed $2.0 \mu \mathrm{g} / \mathrm{l}$ in all available hair samples. All median values of $\mathrm{Ni}$ in hair are below the threshold value of $1.4 \mu \mathrm{g} / \mathrm{kg}$ set by Biolab Medical Unit for $\mathrm{Ni}$ while mean value of $\mathrm{Ni}$ exceeded the threshold value in the black shale area of Kaavi. Maximum $\mathrm{Ni}$ concentrations exceed the threshold value for $\mathrm{Ni}$ in Zambia, Tubinsk (Russia) and in the black shale areas of Sotkamo and Kaavi (Table 6).

In a Swedish study, the median $\mathrm{Mn}$ and $\mathrm{Ni}$ concentrations in hair are reported to be $0.35 \mathrm{mg} / \mathrm{kg}$ and $0.29 \mathrm{mg} / \mathrm{kg}$, and the maximum values are $2.41 \mathrm{mg} / \mathrm{kg}$ and $1.60 \mathrm{mg} / \mathrm{kg}$, respectively (Rodushkin et al. 2000). At Sotkamo and Kaavi, the median and maximum concentrations of $\mathrm{Mn}$ and $\mathrm{Ni}$ hair in the black shale and reference areas were higher than the concentrations reported in the Swedish study (Rodushkin et al., 1999). The chemical characteristics of the Paleoproterozoic bedrock underlying the Swedish study areas differ from the bedrock of our study areas in Finland (Koistinen et al., 2001), while the Quaternary deposits are quite similar (Salminen et al., 2005). In our study, Mn and Ni concentrations in hair were consistent with the ranges from different countries reported by Rodushkin et al. (2000).

In a Russian study, the median Mn concentration in hair is significantly higher in men than in women (Skalny et al., 2015), while in a Greek data set, Ni concentrations in hair are higher in women than men (Sazakli \& Leotsinidis, 2017). In the present data, we found no marked differences in concentrations of $\mathrm{Mn}$ or $\mathrm{Ni}$ in hair in relation to age or between men and women. In comparison with the median Mn concentrations in our study, the authors of a study among a population living in the European part of Russia report lower Mn concentrations in hair, the median being $0.52 \mathrm{mg} / \mathrm{kg}$ (Skalny et al., 2015). One potential explanation is that the underlying bedrock of the European part of Russia is mostly different from the bedrock in the Palaeoproterozoic Fennoscandian Shield in our study areas (Koistinen et al., 2001). Age, sex, length of residence and smoking years did not correlate with $\mathrm{Mn}$ or $\mathrm{Ni}$ concentrations in hair among the participants in our study.

Drinking water from private wells

Sulphide-rich rocks are potential natural sources of environmental exposure to trace elements via well water. In the black shale areas, the elevated $\mathrm{Mn}$ concentration in bedrock well water results from the long retention time of water passing through bedrock fractures as well as from the prevailing reducing conditions in these wells (Korkka-Niemi, 2001). In Finland, well waters from Quaternary deposits are slightly more acidic than those from deep bedrock wells resulting in the dissolution of metals, including $\mathrm{Ni}$, into the water. In addition, old dug wells and household plumbing systems may promote $\mathrm{Ni}$ dissolution into water (Lahermo et al., 2002). The Mn and $\mathrm{Ni}$ concentrations in water were on average slightly higher in both well types in the black shale areas compared to the average concentrations for thousands of private wells the Geological Survey of Finland has studied in Finland. In the reference areas, the Mn concentrations in water were lower, while the $\mathrm{Ni}$ concentrations in water were higher than the average for the whole country (Lahermo et al., 2002). 
In Finland and other Nordic countries, over $90 \%$ of households are within the municipal water supply system (Gunnarsdottir et al., 2020). Approximately $10 \%$ of the total Finnish population uses water for drinking, washing and irrigation from private singlehousehold wells. An increasing number of summer houses increase the amount of private well water users during holiday seasons (Lahermo et al., 2002).

Mining activities in a naturally sulphide-rich site

Our results provided background data for the evaluation of the impact of mining activities to human health. Mining of the large black-shale-hosted Ni-Zn$\mathrm{Cu}-\mathrm{Co}$ deposit at Talvivaara started in 2008 in our sulphur-rich study area in Sotkamo. Our results represent geochemical background levels since we carried out sampling already in 1999, well before the mining activities began. We recommend geochemical background studies and the monitoring of the quality of groundwater and surface waters before starting mining operations since in most cases the bedrock and soil contain potentially harmful elements and compounds already under natural conditions in a sulphide mine site. The risks to groundwater, surface waters and human health due to civil engineering and other anthropogenic actions are higher than in areas with naturally sulphide-poor bedrock and soil.

\section{Conclusions}

The results of our study indicated that natural exposure to elevated concentrations of $\mathrm{Mn}$ and $\mathrm{Ni}$ in drinking water can be detected in human hair samples. The average levels of $\mathrm{Mn}$ and $\mathrm{Ni}$ in well water in our study areas in Sotkamo and Kaavi, eastern Finland, were below the guidelines set by the Finnish national regulations. The biological samples, the serum $\mathrm{Ca}, \mathrm{Zn}$, $\mathrm{Cu}, \mathrm{Se}$ and $\mathrm{B}-\mathrm{Se}$ and $\mathrm{B}-\mathrm{Cd}$ concentrations, did not associate with the concentrations of those elements in well water or human hair. The chemical composition of the biological samples studied did not vary between sulphidic and sulphur-poor areas except for serum $\mathrm{Ca}$ which was slightly lower in sulphidic areas. The limitation of the present study was the small number of residents due to the low population density in the study areas in rural Finland. In spite of this challenge, our study described the effects of sulphur-rich bedrock and soil to human population under natural conditions. Sulphur-rich bedrock areas are encountered in highly populated countries like China, South Korea and some African countries (e.g. Parviainen \& Loukola-Ruskeeniemi, 2019).

Acknowledgements This work was supported by the Geological Survey of Finland GTK and the University of Eastern Finland (formerly the University of Kuopio). We thank the voluntary participants of the research and the medical personnel of the healthcare centres of Sotkamo and Kaavi who took the hair and blood samples.

Authors' contributions AK took part in writing original draft, review \& editing/ investigation/ methodology. KL involved in writing original draft, review \& editing/ investigation/ conceptualization/methodology. MK participated in writing original draft/ investigation/conceptualization/ methodology. TH took part in writing original draft/ investigation.

Data availability The data that support the findings of this study are available on request from Dr. Kirsti LoukolaRuskeeniemi.

\section{Declarations}

Conflict of interest The authors declare that they have no known competing financial interests or personal relationships that could have appeared to influence the work reported in this paper.

Consent to participate Informed consent was obtained from all individual participants included in the study.

Consent to publish The participant has consented to the submission of the study to the journal.

Open Access This article is licensed under a Creative Commons Attribution 4.0 International License, which permits use, sharing, adaptation, distribution and reproduction in any medium or format, as long as you give appropriate credit to the original author(s) and the source, provide a link to the Creative Commons licence, and indicate if changes were made. The images or other third party material in this article are included in the article's Creative Commons licence, unless indicated otherwise in a credit line to the material. If material is not included in the article's Creative Commons licence and your intended use is not permitted by statutory regulation or exceeds the permitted use, you will need to obtain permission directly from the copyright holder. To view a copy of this licence, visit http://creativecommons.org/licenses/by/4.0/.

\section{References}

Amaral, A. F. S., Arruda, M., Cabral, S., \& Rodrigues, A. S. (2008). Essential and non-essential trace metals in scalp hair of men chronically exposed to volcanogenic metals in 
the Azores, Portugal. Environment International, 34, 1104-1108.

Arkimaa, H., Hyvönen, E., Lerssi, J., Loukola-Ruskeeniemi, K., Vanne, J. (1999). Compilation of maps of black shales in Finland: applications for exploration and environmental studies. In: Autio, S. (Ed.) Geological Survey of Finland. Special Paper. Current Research 1997-1998. Vol. 27, pp. 111-114. https://tupa.gtk.fi/julkaisu/specialpaper/sp_ 027.pdf

Arkimaa, H., Hyvönen, E., Lerssi, J., Loukola-Ruskeeniemi, K., Vanne, J. (2000). Proterozoic Black Shale Formations and Aeromagnetic Anomalies in Finland. 1: 1000 000. (Map and database) Geological Survey of Finland, Espoo, Finland.

ATSDR. Agency for Toxic Substances and Disease Registry. (2008). Toxicological Profile for Cadmium (Draft for Public Comment). Atlanta, GA: U.S. Department of Health and Human Services, Public Health Service. Page last reviewed: March 12, 2015.

ATSDR Agency for Toxic Substances and Disease Registry. (2005a). Toxicological profile for Nickel. Atlanta, GA: U.S. Department of Health and Human Services, Public Health Service. https://wwwn.cdc.gov/TSP/ToxProfiles/ ToxProfiles.aspx id=245\&tid $=44$

ATSDR Agency for Toxic Substances and Disease Registry. (2012). Toxicological profile for Manganese. Atlanta, GA: U.S. Department of Health and Human Services, Public Health Service. https://wwwn.cdc.gov/TSP/ToxProfiles/ ToxProfiles.aspx id $=102 \&$ tid $=23$

ATSDR. Agency for Toxic Substances and Disease Registry. (2003). Toxicological Profile for Selenium (Update). U.S. Department of Health and Human Services, Public Health Service.

ATSDR. Agency for Toxic Substances and Disease Registry. (2005b). Toxicological Profile for Zinc. U.S. Department of Health and Human Services, Public Health Service.

Barbagallo, M., \& Dominguez, L. J. (2007). Magnesium metabolism in type 2 diabetes mellitus, metabolic syndrome and insulin resistance. Archives of Biochemistry and Biophysics., 458, 40-47.

Barbeau, B., Carrière, A., \& Bouchard, M. F. (2011). Spatial and temporal variations of manganese concentrations in drinking water. Journal of Environmental Science and Health Part A., 6, 608-616.

Barceloux, D. G. (1999). Copper. Journal of Toxicology Clinical Toxicology, 37(2), 217-230. https://doi.org/10. 1081/clt-100102421 PMID: 10382557.

Bedrock of Finland - DigiKP. Digital map database [Electronic resource]. Espoo: Geological Survey of Finland [referred 20.09.2021]. Version 2.1.

Begum, S., Shah, M. T., Muhammad, S., \& Khan, S. (2015). Role of mafic and ultramafic rocks in drinking water quality and its potential health risk assessment. Northern Pakistan. Journal of Water \& Health, 13(4), 1130-1142. https://doi.org/10.2166/wh.2015.066

Bellesteros, L., Serrano, N., \& Álvarez, I. S. (2017). Reference levels of trace elements in hair samples from children and adolescents in Madrid Spain. Journal of trace elements in medicine and biology, 43, 113-120. https://doi.org/10. 1016/j.jtemb.2016.12.010 Epub 2016 Dec 29.
Biolab Medical Unit. 2012. Nutritional and environmental medicine. https://www.biolab.co.uk/docs/Hair_Mineral_ Analysis.pdf. Accessed May, 2021.

Bost, M., Houdart, S., Oberli, M., Kalonji, E., Huneau, J., \& Margaritis, I. (2016). Dietary copper and human health: Current evidence and unresolved issues. Journal of Trace Elements in Medicine and Biology, 35, 107-115. https:// doi.org/10.1016/j.jtemb.2016.02.006

Bouchard, M. F., Sauve, S., Barbeau, B., Legrand, M., Brodeur, M. E., Bouffard, T., et al. (2011). Intellectual impairment in school-age children exposed to manganese from drinking water. Environmental Health Perspectives., 119, 138-143.

Chafe, R., Aslanov, R., Sarkar, A., Gregory, P., Comeau, A., \& Newhook, L. A. (2018). Association of type 1 diabetes and concentrations of drinking water components in Newfoundland and Labrador, Canada. BMJ Open Diabetes Research \& Care., 6(1), e000466. https://doi.org/10.1136/ bmjdrc-2017-000466

Chen, L., Zhou, S., Shi, Y., Wang, C., Li, B., Li, Y., \& Wu, S. (2018). Heavy metals in food crops, soil, and water in the Lihe River Watershed of the Taihu Region and their potential health risks when ingested. Science of the Total Environment, 15(615), 141-149. https://doi.org/10.1016/j. scitotenv.2017.09.230

EFSA European Food Safety Authority. (2020). Update of the risk assessment of nickel in food and drinking water. EFSA Journal, 18(11), 6268. https://doi.org/10.2903/j.efsa.2020. 6268

Fairweather-Tait, S. J., \& Teucher, B. (2002). Iron and calcium bioavailability of fortified foods and dietary supplements. Nutrition Reviews, 60, 360-367.

Gil, F., Hernández, A. F., Márquez, C., Femia, P., Olmedo, P., López-Guarnido, O., \& Pla, A. (2011). Biomonitorization of cadmium, chromium, manganese, nickel and lead in whole blood, urine, axillary hair and saliva in an occupationally exposed population. Science of The Total Environment, 409(6), 1172-80. https://doi.org/10.1016/j. scitotenv.2010.11.033

Gunnarsdottir, M. J., Gardarsson, S. M., Schultz, A. C., et al. (2020). Status of risk-based approach and national framework for safe drinking water in small water supplies of the Nordic water sector. International Journal of Hygiene and Environmental Health, 230, 113627. https://doi.org/10. 1016/j.ijheh.2020.113627

Gustavsson, N., Loukola-Ruskeeniemi, K., \& Tenhola, M. (2011). Evaluation of natural geochemical background levels. Geoscience for Society 125th Anniversary Volume. Geological Survey of Finland. Special Paper, 49, 237-246.

Gustavsson, N., Loukola-Ruskeeniemi, K., \& Tenhola, M. (2012). Evaluation of geochemical background levels around sulfide mines - a new statistical procedure with beanplots. Applied Geochemistry, 27(1), 240-249.

Haber, L. T., Bates, H. K., Allen, B. C., Vincent, M. J., \& Oller, A. R. (2017). Derivation of an oral toxicity reference value for nickel. Regulatory Toxicology and Pharmacology, 15(87 Suppl 1), S1-S18. https://doi.org/10.1016/j.yrtph. 2017.03.011

UCLA Health (2021). Normal Calcium Levels. https://www. uclahealth.org/endocrine-center/normal-calcium-levels (available 22 Sep 2021). 
Heaney, R. P., Recker, R., \& R., Stegman M, R., Moy, A.J. (1989). Calcium absorption in women: Relationships to calcium intake, estrogen status, and age. Journal of Bone and Mineral Research, 4, 469-475.

Hyvönen, E., Airo, M.-L., Arkimaa, H., Lerssi, J., LoukolaRuskeeniemi, K., Vanne, J., \& Vuoriainen, S. (2013). Airborne geophysical, petrophysical and geochemical characteristics of Palaeoproterozoic black shale units in Finland Applications for exploration and environmental studies. Report of Investigation - Geological Survey of Finland., 198, 58-60.

Jarup, L., Berglund, M., Elinder, C. G., Nordberg, G., \& Vahter, M. (1998). Health effects of cadmium exposure-a review of the literature and a risk estimate. Scandinavian Journal of Work, Environment \& Health, 24(Suppl 1), 1-51.

Jiang, L., He, P., Chen, J., Liu, Y., Liu, D., Qin, G., \& Tan, N. (2016). Magnesium Levels in Drinking Water and Coronary Heart Disease Mortality Risk: A Meta-Analysis. Nutrients, 8(1), 5. https://doi.org/10.3390/nu8010005

Khan, B., Nowson, C. A., Daly, R. M., English, D. R., Hodge, A. M., Giles, G. G., et al. (2015). Higher dietary calcium intakes are associated with reduced risks of fractures, cardiovascular events, and mortality: A prospective cohort study of older men and women. Journal of Bone and Mineral Research, 30, 1758-1766.

Khot, U. N., Khot, M. B., Bajzer, C. T., et al. (2003). Prevalence of Conventional Risk Factors in Patients With Coronary Heart Disease. JAMA, 290(7), 898-904. https://doi.org/10. 1001/jama.290.7.898

Kim, K. W., \& Thornton, I. (1993). Influence of uraniferous black shales on cadmium, molybdenum and selenium in soils and crop plants in the Deog-Pyoun-g area of Korea. Environmental Geochemistry and Health, 15, 119-133. https://doi.org/10.1007/BF02627830

Koistinen, T., Stephens, M.B., Bogatchev, V., Nordgulen, Ø., Wennerström, M., Korhonen, J. (comp.) (2001). Geological map of the Fennoscandian Shield, scale 1:2,000,000. Espoo: Geological Survey of Finland, Trondheim: Geological Survey of Norway, Uppsala: Geological Survey of Sweden, Moscow: Ministry of Natural Resources of Russia.

Korkka-Niemi K. 2001. Cumulative geological, regional and site-specific factors affecting groundwater quality in domestic wells in Finland. Monographs of the Boreal Environmental Research 20. Finnish Environmental Institute, Finland, Helsinki. 98 p.

Kousa, A., Havulinna, A. S., Moltchanova, E., Taskinen, O., Nikkarinen, M., Eriksson, J., \& Karvonen, M. (2006). Calcium to magnesium ratio in local ground water and incidence of acute myocardial infarction among males in rural Finland. Environmental Health Perspectives, 114, 730-734. https://doi.org/10.1289/ehp.8438

Kousa, A., Havulinna, A. S., Moltchanova, E., Taskinen, O., Nikkarinen, M., Salomaa, V., \& Karvonen, M. (2008). Magnesium in well water and the spatial variation of AMI incidence in rural Finland. Applied Geochemistry, 23(632-640), 2008. https://doi.org/10.1016/j.apgeochem. 2007.10.015

Kousa, A., Puustinen, N., Karvonen, M., \& Moltchanova, E. (2012). The regional association of rising type 2 diabetes incidence with magnesium in drinking water among young adults. Environmental Research, 112, 126-128. https://doi. org/10.1016/j.envres.2011.11.001 Epub 2011 Nov 20 PMID: 22104701.

Kousa, A., Komulainen, H., Hatakka, T., Backman, B., \& Hartikainen, S. (2021). Variation in groundwater manganese in Finland. Environmental Geochemistry and Health, 43(3), 1193-1211.

Lahermo. P., Tarvainen, T., Hatakka, T., Backman, B., Juntunen, R., Kortelainen, N., Lakomaa, T., Nikkarinen, M., Vesterbacka, P., Väisänen, U., Suomela, P. (2002). Summary: One thousand wells - the physical-chemical quality of Finnish well waters in 1999 (in Finnish). Geological Survey of Finland. Report of Investigation 155. Espoo. https://tupa.gtk.fi/julkaisu/tutkimusraportti/tr_155.pdf

Laine, J. T., Tuomainen, T. P., Salonen, J. T., et al. (2020). Serum copper-to-zinc-ratio and risk of incident infection in men: the Kuopio Ischaemic Heart Disease Risk Factor Study. European Journal of Epidemiology, 35, 1149-1156.

Loukola-Ruskeeniemi K. (1992). Geochemistry of Proterozoic metamorphosed black shales in eastern Finland, with implications for exploration and environmental studies. Geological Survey of Finland. Erikoisjulkaisut - Special Publications 9, $86 \mathrm{p}$.

Loukola-Ruskeeniemi, K. (1999). Origin of black shales and the serpentinite-associated $\mathrm{Cu}-\mathrm{Zn}-\mathrm{Co}$ ores at Outokumpu in Finland. Economic Geology, 94, 1007-1028. https://doi. org/10.2113/gsecongeo.94.7.1007

Loukola-Ruskeeniemi, K., \& Heino, T. (1996). Geochemistry and genesis of the black shale-hosted $\mathrm{Ni}-\mathrm{Cu}-\mathrm{Zn}$ deposit at Talvivaara, Finland. Economic Geology, 91(1), 80-110.

Loukola-Ruskeeniemi, K., Uutela, A., Tenhola, M., \& Paukola, T. (1998). Environmental impact of metalliferous black shales in Finland, with indication of lake acidification 9000 years ago. Journal of Geochemical Exploration, 64, 395-407.

Loukola-Ruskeeniemi, K., Kantola, M., Henttonen, P., Halonen, T., Paukola, T., Seppänen, K., Kallio, E., Ilmasti, M., Vanne, J., Timonen, O., \& Kollaan, K. (1999). Migration of potentially harmful elements from black shales to aquatic ecosystems and local residents: Preliminary results in Eastern Finland. Geological Survey of Finland. Special Paper, 27, 107-110.

Loukola-Ruskeeniemi, K., Kantola, M., Halonen, T., Seppänen, K., Henttonen, P., Kallio, E., Kurki, P., \& Savolainen, H. (2003). Mercury-bearing black shales and human $\mathrm{Hg}$ intake in eastern Finland: impact and mechanisms. Environmental Geology, 43(3), 283-297.

Loukola-Ruskeeniemi, K., Hyvönen, E., Airo, M-L., Arkimaa, H., Eskelinen, J., Lerss,i J., Vanne, J., Vuoriainen, S. (2011). Onko Suomessa uusia Talvivaara-tyyppisiä malmeja? Geofysikaalisiin ja geokemiallisiin tutkimuksiin perustuvat Suomen mustaliuskekartta. Abstract: Evaluation of the ore potential of black shale units in Finland preliminary results of a geophysical and geochemical study. Geologi 3, 68-79. https://www.geologinenseura.fi/ sites/geologinenseura.fi/files/geologi_-_artikkelit/ mustaliuske.pdf

McLeod, L., Bharadwaj, L., Epp, T. Y., \& Waldner, C. (2018). Ecological analysis of associations between groundwater quality and hypertension and cardiovascular disease in rural Saskatchewan, Canada using Bayesian hierarchical 
models and administrative health data. Environmental Research, 31(167), 329-340. https://doi.org/10.1016/j. envres.2018.07.038

Mikulewicz, M., Chojnacka, K., Gedrange, T., \& Górecki, H. (2013). Reference values of elements in human hair: a systematic review. Environmental Toxicology and Pharmacology., 36(3), 1077-86. https://doi.org/10.1016/j.etap. 2013.09.012

Moltchanova, E., Rytkönen, M., Kousa, A., Taskinen, O., Tuomilehto, J., \& Karvonen, M. (2004). Zinc and nitrate in the ground water and the incidence of Type 1 diabetes in Finland. Diabetic Medicine, 21(3), 256-261. https://doi. org/10.1111/j.1464-5491.2004.01125.x

Munakata, M., \& Onum, a A., Kobayashi, Y., Haginoya, K., Yokoyama, H., Fujiwara, I., Yasuda, H., Tsutsui, T., Iinuma, K. (2006). A preliminary analysis of trace elements in the scalp hair of patients with severe motor disabilities receiving enteral nutrition. Brain \& Development, 28(8), 521-525. https://doi.org/10.1016/j.braindev.2006.02.004

Nakaona, L., Maseka, K. K., Hamilton, E. M., \& Watts, M. J. (2020). Using human hair and nails as biomarkers to assess exposure of potentially harmful elements to populations living near mine waste dumps. Environmental Geochemistry and Health, 42(4), 1197-1209. https://doi.org/10. 1007/s10653-019-00376-6 Epub 2019 Jul 17 PMID: 31317372 .

Ntihabose, R., Surette, C., Foucher, D., Clarisse, O., \& Bouchard, M. F. (2018). Assessment of saliva, hair and toenails as biomarkers of low level exposure to manganese from drinking water in children. Neurotoxicology, 64, 126-133. https://doi.org/10.1016/j.neuro.2017.08.011 Epub 2017 Sep 1 PMID: 28867366.

O’Neal, S. L., \& Zheng, W. (2015). Manganese Toxicity Upon Overexposure: A Decade in Review. Curr Environ Health Rep., 2(3), 315-328. https://doi.org/10.1007/s40572-0150056-X

Oulhote, Y., Mergler, D., Barbeau, B., Bellinger, D. C., Bouffard, T., Brodeur, M. E., et al. (2014). Neurobehavioral function in school-age children exposed to manganese in drinking water. Environmental Health Perspectives, 122, 1343-1350. https://doi.org/10.1289/ehp.1307918

Pänkäläinen, M. T., Kerola, T. V., \& Hintikka, J. J. (2015). Pessimism and the risk for coronary heart disease among middle-aged and older Finnish men and women: A ten-year follow-up study. BMC Cardiovascular Disorders, 15, 113. https://doi.org/10.1186/s12872-015-0097-y

Parviainen, A., \& Loukola-Ruskeeniemi, K. (2019). Environmental impact of mineralised black shales. Earth-Science Reviews, 192, 65-90. https://doi.org/10.1016/j.earscirev. 2019.01.017

Pereira, R., Ribeiro, R., \& Gonçalves, F. (2004). Scalp hair analysis as a tool in assessing human exposure to heavy metals (S Domingos mine, Portugal). Science of The Total Environment, 327(1-3), 81-92.

Piispanen, R., \& Nykyri, T. (1997). Acidification of groundwater in water-filled gravel pits - a new environmental and geomedical threat. Environmental Geochemistry and Health, 19, 111-126. https://doi.org/10.1023/A: 1018454622669

Razagui, I. B., \& Ghribi, I. (2005). Maternal and neonatal scalp hair concentrations of zinc, copper, cadmium, and lead:
Relationship to some lifestyle factors. Biological Trace Element Research, 106(1), 1-28. https://doi.org/10.1385/ BTER:106:1:001 PMID: 16037607.

Rodushkin, I., \& Axelsson, M. D. (2000). Application of double focusing sector field ICP-MS for multielemental characterization of human hair and nails Part II A study of the inhabitants of northern Sweden. Science of The Total Environment., 262(1-2), 21-36.

Rodushkin, I., Ödman, F., \& Holmström, H. (1999). Multielement analysis of wild berries from northern Sweden by ICP techniques. Science of the Total Environment, 231, 53-65. https://doi.org/10.1016/S0048-9697(99)00080-7

Rohrmann, S., Garmo, H., Malmström, H., Hammar, N., Jungner, I., Walldius, G., \& Van Hemelrijck, M. (2016). Association between serum calcium concentration and risk of incident and fatal cardiovascular disease in the prospective AMORIS study. Atherosclerosis, 251, 85-93. https://doi.org/10.1016/j.atherosclerosis.2016.06.004

Rubenowitz, E., Molin, I., Axelsson, G., \& Rylander, R. (2000). Magnesium in drinking water in relation to morbidity and mortality from acute myocardial infarction. Epidemiology, $11,416-421$.

Sabanayagam, C., \& Shankar, A. (2011). Serum calcium levels and hypertension among US adults. The Journal of Clinical Hypertension., 13(10), 716-21. https://doi.org/10.1111/j. 1751-7176.2011.00503.x

Salminen, R. (Chief-Ed.), Batista, M. J., Bidovec, M., Demetriades, A., De Vivo, B., De Vos, W., et al. (2005). Geochemical Atlas of Europe. Part 1 - Background Information, Methodology and Maps. Geological Survey of Finland, Espoo, Finland.

Satarug, S., Nishijo, M., Ujjin, P., \& Moore, M. R. (2018). Chronic exposure to low-level cadmium induced zinccopper dysreglation. Journal of Trace Elements in Medicine and Biology., 46, 32-8.

Sazakli, E., \& Leotsinidis, M. (2017). Hair biomonitoring and health status of a general population exposed to Nickel. Journal of Trace Elements in Medicine and Biology, 43, 161-168. https://doi.org/10.1016/j.jtemb.2017.02.001

Schullehner, J., Thygesen, M., Kristiansen, S. M., Hansen, B., Pedersen, C. B., \& Dalsgaard, S. (2020). Exposure to Manganese in Drinking Water during Childhood and Association with Attention-Deficit Hyperactivity Disorder A Nationwide Cohort Study. Environmental Health Perspectives, 128(9), 97004. https://doi.org/10.1289/ EHP6391

Semenova, N., Rafikova, Yu. S., Khasanova, R. F., \& Suyundukov Ya.T. (2018). Analysis of metal content in soils near abandoned mines of Bashkir Trans Urals and in the hair of children living in this territory. Journal of Trace Elements in Medicine and Biology, 50, 664-670. https://doi.org/10. 1016/j.jtemb.2018.06.017

Singh-Manoux, A., Fayosse, A., Sabia, S., Tabak, A., Shipley, M., Dugravot, A., \& Kivimäki, M. (2018). Clinical, socioeconomic, and behavioural factors at age 50 years and risk of cardiometabolic multimorbidity and mortality: A cohort study. PLoS Medicine, 15(5), e1002571. https://doi. org/10.1371/journal.pmed.1002571

Skalny, A. V., Skalnaya, M. G., Tinkov, A. A., Serebryansky, E. P., Demidov, V. A., Lobanova, Y. N., Grabeklis, A. R., Berezkina, E. S., Gryazeva, I. V., Skalny, A. A., Skalnaya, 
O. A., Zhivaev, N. G., \& Nikonorov, A. A. (2015). Hair concentration of essential trace elements in adult non-exposed Russian population. Environmental Monitoring and Assessment, 187(11), 677. https://doi.org/10.1007/s10661015-4903-x Epub 2015.

Skröder, H., Kippler, M., Nermell, B., Tofail, F., Levi, M., Rahman, S. M., Raqib, R., \& Vahter, M. (2017). Major Limitations in Using Element Concentrations in Hair as Biomarkers of Exposure to Toxic and Essential Trace Elements in Children. Environ Health Perspect. https://doi. org/10.1289/EHP1239

STM Ministry of social affairs and health (2001). Decree of the Ministry of Social Affairs and Health on the quality requirements and control examinations of drinking water in small units (401/2001). The Ministry of Social Affairs and Health, Finland.

STM Ministry of social affairs and health (2015). The Decree of the Ministry of Social Affairs and Health relating to the quality and monitoring of water Intended for human consumption (1352/2015). The Ministry of Social Affairs and Health, Finland.
Tamburo, E., Varrica, D., \& Dongarrà, G. (2016). Gender as a key factor in trace metal and metalloid content of human scalp hair. A Multi-Site Study. Sci Total Environ., 15(573), 996-1002. https://doi.org/10.1016/j.scitotenv.2016.08.178 Epub 2016 Sep 5 PMID: 27607902.

Viana, G. F., de Carvalho, C. F., Nunes, L. S., Rodrigues, J. L., Ribeiro, N. S., de Almeida, D. A., Ferreira, J. R., Abreu, N., \& Menezes-Filho, J. A. (2014). Noninvasive biomarkers of manganese exposure and neuropsychological effects in environmentally exposed adults in Brazil. Toxicology Letter., 231(2), 169-78.

Zeng, A., Li, S., Zhou, Y., et al. (2021). Association Between Low-Level Blood Cadmium Exposure and Hyperuricemia in the American General Population: A Cross-sectional Study. Biological Trace Element Research. https://doi.org/ 10.1007/s12011-021-02700-7

Publisher's Note Springer Nature remains neutral with regard to jurisdictional claims in published maps and institutional affiliations. 